University of Nebraska - Lincoln

DigitalCommons@University of Nebraska - Lincoln

2019

TIME-DOMAIN AND FREQUENCY-DOMAIN REFLECTOMETRY

TYPE SOIL MOISTURE SENSOR PERFORMANCE AND SOIL

TEMPERATURE EFFECTS IN FINE- AND COARSE-TEXTURED

SOILS

Y. Zhu

S. Irmak

A. J. Jhala

M. C. Vuran

A. Diotto

Follow this and additional works at: https://digitalcommons.unl.edu/biosysengfacpub

Part of the Bioresource and Agricultural Engineering Commons, Environmental Engineering Commons, and the Other Civil and Environmental Engineering Commons

This Article is brought to you for free and open access by the Biological Systems Engineering at

DigitalCommons@University of Nebraska - Lincoln. It has been accepted for inclusion in Biological Systems

Engineering: Papers and Publications by an authorized administrator of DigitalCommons@University of Nebraska -

Lincoln. 


\title{
TIME-DOMAIN AND FREQUENCY-DOMAIN REFLECTOMETRY TYPE SOIL MOISTURE SENSOR PERFORMANCE AND SOIL TEMPERATURE EFFECTS IN FINE- AND COARSE-TEXTURED SOILS
}

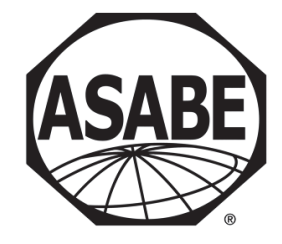

\author{
Y. Zhu, S. Irmak, A.J. Jhala, M.C. Vuran, A. Diotto
}

\begin{abstract}
The performances of six time-domain reflectometry (TDR) and frequency-domain reflectometry (FDR) type soil moisture sensors were investigated for measuring volumetric soil-water content $\left(\theta_{v}\right)$ in two different soil types. Soilspecific calibration equations were developed for each sensor using calibrated neutron probe-measured $\theta_{v}$. Sensors were also investigated for their performance response in measuring $\theta_{v}$ to changes in soil temperature. The performance of all sensors was significantly different $(P<0.05)$ than the neutron probe-measured $\theta_{v}$, with the same sensor also exhibiting variation between soils. In the silt loam soil, the 5TE sensor had the lowest root mean squared error (RMSE) of 0.041 $\mathrm{m}^{3} / \mathrm{m}^{3}$, indicating the best performance among all sensors investigated. The performance ranking of the other sensors from high performance to low was: TDR300 (High Clay Mode), CS616 (H) and 10HS, SM150, TDR300 (Standard Mode), and CS616 (V) (H: horizontal installation and V: vertical installation). In the loamy sand, the CS616 (H) performed best with an RMSE of $0.014 \mathrm{~m}^{3} / \mathrm{m}^{3}$ and the performance ranking of other sensors was: 5TE, CS616 (V), TDR300 (S), SM150, and 10HS. When $\theta_{v}$ was near or above field capacity, the performance error of most sensors increased. Most sensors exhibited a linear response to increase in soil temperature. Most sensors exhibited substantial sensitivity to changes in soil temperature and the $\theta_{v}$ response of the same sensor to high vs. normal soil temperatures differed significantly between the soils. All sensors underestimated $\theta_{v}$ in high temperature range in both soils. The ranking order of the magnitude of change in $\theta_{v}$ in response to $1^{\circ} \mathrm{C}$ increase in soil temperature (from the lowest to the greatest impact of soil temperature on sensor performance) in silt loam soil was: SM150, 5TE, TDR300 (S), 10HS, CS620, CS616 (H), and CS616 (V). The ranking order from lower to higher sensitivity to soil temperature changes in loamy sand was: 10HS, CS616 (H), 5TE, CS616 (V), SM150, and TDR300 (S). When the data from all sensors and soils are pooled, the overall average of change in $\theta_{v}$ for a $1{ }^{\circ} \mathrm{C}$ increase in soil temperature was $0.21 \mathrm{~m}^{3} / \mathrm{m}^{3}$ in silt loam soil and $-0.052 \mathrm{~m}^{3} / \mathrm{m}^{3}$ in loamy sand. When all $T D R$ - and FDR-type sensors were pooled separately for both soils, the average change in $\theta_{v}$ for a $1^{\circ} \mathrm{C}$ increase in soil temperature for the TDR- and FDR-type sensors was 0.1918 and $-0.0273 \mathrm{~m}^{3} / \mathrm{m}^{3}$, respectively, indicating that overall TDRtype sensors are more sensitive to soil temperature changes than FDR-type sensors when measuring $\theta_{v}$.
\end{abstract}

Keywords. Capacitance, Frequency-domain reflectometry, Soil moisture, Time-domain reflectometry.

Submitted for review in April 2018 as manuscript number ITSC 12908; approved for publication by the Information Technology, Sensors, \& Control Systems Community of ASABE in January 2019.

This work was conducted as a part of first author's Master's study while a graduate student in the Irmak Research Laboratory's research program at the University of Nebraska-Lincoln under the supervision of Dr. Suat Irmak.

The mention of the trade names or commercial products is for the information of the readers and does not constitute an endorsement or recommendation for use by the authors or their institutions.

The authors are Yan Zhu, former Graduate Student in the Irmak Research Laboratory at the University of Nebraska-Lincoln (UNL); Suat Irmak, Distinguished Professor, UNL; Amit J. Jhala, Assistant Professor, Department of Agronomy and Horticulture, UNL; Mehmet C. Vuran, Associate Professor, Department of Computer Science and Engineering, UNL; Adriano Diotto, former Postdoctoral Research Associate in the Irmak Research Laboratory at UNL. Corresponding author: Suat Irmak, University of Nebraska-Lincoln, 239 L.W. Chase Hall, Lincoln, NE 68583-0726; phone: 402-472-4865; e-mail: sirmak2@unl.edu.

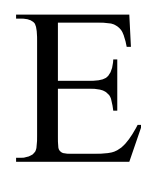

ffective irrigation scheduling requires understanding of the dynamics of soil-water storage in the plant root-zone and soil-water availability and use by plants, which relies on the accurate measurement of soil moisture. Methods used for quantifying soil-water include gravimetric method, time domain reflectometry, ground penetrating radar, capacitance, radar scatterometry or active or passive microwaves, electromagnetic induction, neutron thermalization, nuclear magnetic resonance, gamma ray attenuation, resistive sensors, tensiometry, hygrometric techniques, remote sensing, and optical methods. The performance of each method can vary with the soil textural, chemical, and physical properties, soil temperature, and soil moisture range in which they are operated (Irmak and Irmak, 2005). Over the past few decades, growers and their advisors in the United States and in other areas of the world 
have been increasingly advised to take advantage of emerging technologies based on soil moisture sensing to help them determine the appropriate timing and amount of irrigation (Irmak et al., 2010). It is critical to deploy properly calibrated soil moisture sensors in practice. Although sensors may be tested by manufacturers in laboratory settings before they are released to the market, in many cases the effectiveness of such tests is limited by specific laboratory configurations and soil types as well as calibration quality and/or procedures. Sensors may differ in performance under conditions specific to different local measurement locations due to a number of environmental factors. For example, clay content, soil temperature, texture, salinity, air gap between the soil and the sensor, porosity, and bulk density can exert different levels of influence on the sensor performance (Annan, 1977; Knight, 1992; Robinson and Dean, 1993; White et al., 1994; Paltineanu and Starr, 1997; Wraith and Or, 1999; Gong et al., 2003; Irmak and Irmak, 2005).

Numerous sensor performance and performanceinfluencing factors experiments have been conducted under laboratory and field conditions (Leib et al., 2003; Plauborg et al., 2005; Chandler et al., 2004; Ojo et al., 2014, 2015; Miller et al., 2014; Soulis et al., 2015; Visconti et al., 2014; Jabro et al., 2017; Kargas et al., 2019). Vaz et al. (2013) evaluated eight commercially available electromagnetic water content sensors (TDR100, CS616, Theta Probe, Hydra Probe, SM300, Wet2, 5TE, 10HS) in soils, ranging from sand to clay, including an organic soil. They observed that the factory-supplied calibration relationships for groups of mineral and organic soils in general performed well, but also substantial inconsistences were identified. Soil-specific calibrations resulted in accuracies of $0.015 \mathrm{~m}^{3}$ $\mathrm{m}^{-3}$ for $10 \mathrm{HS}$, SM300, and Theta Probe, while they found much lower accuracies of about $0.025 \mathrm{~m}^{3} \mathrm{~m}^{-3}$ for TDR100, CS616, Wet2, 5TE, and the Hydra Probe. Evett and Steiner (1995) determined the relative precision of two brands of neutron scattering gauges (three gauges of each) and a brand of capacitance sensors (four sensors) in a field calibration under loamy fine sand and sandy clay loam soils. Both brands of neutron scattering gauges were calibrated against volumetric soil-water content $\left(\theta_{\mathrm{v}}\right)$ with coefficients of determination $\left(\mathrm{R}^{2}\right)$ ranging from 0.97 to 0.99 and RMSE less than $0.012 \mathrm{~m}^{3} / \mathrm{m}^{3}$. Calibration for the capacitance probes resulted in $\mathrm{R}^{2}$ ranging from 0.68 to 0.71 and higher RMSE of $0.036 \mathrm{~m}^{3} / \mathrm{m}^{3}$. These results were reproducible among four capacitance sensors. They concluded that the capacitance probe had limited precision under their research conditions, while more accurate results corroborated with neutron scattering gauges illustrated the effectiveness of this technique for calibrating other sensors. Irmak and Irmak (2005) calibrated and evaluated frequency-domain reflectometry (FDR), capacitance and pseudo-transit time (PTT)-based probes in four coarsetextured soils in large lysimeters and concluded that CS615-FDR-measured $\theta_{\mathrm{v}}$ values were closest to those measured by gravimetric soil sampling. The TRIME-PTT probe estimates were significantly $(P<0.05)$ different than the measured values for all soils. The PR1 capacitance type probe had the least accurate results and overestimated in all ranges of $\theta_{\mathrm{v}}$.

\section{Soil Temperature EfFect on Sensor Performance}

Many of the soil moisture sensing technologies measure $\theta_{\mathrm{v}}$ indirectly by using dielectric properties, electrical resistance, amount of hydrogen, or the reflectance properties of the soil, all of which are influenced, by varying degrees, by the amount of water in the soil. The soil dielectric property [which is the basis for FDR and TDR-based sensors (Topp et al., 1980; Fellner-Feldegg, 1969; Davis and Chudobiak, 1975; Dalton et al., 1984; Dalton, 1992)] measurements can be influenced by environmental factors other than water content (Gong et al., 2003). It has been shown that the soil temperature variation can affect soil dielectric properties (Pepin et al., 1995; Wraith and Or, 1999), which may influence the performance of TDR or FDR-type sensors. Thus, investigating the effect(s) of soil temperature on sensor performance is critical to identify sensor performance-influencing factors and their magnitudes, which can be used to enhance sensor design, engineering, circuits, etc. and provide guidance in terms of a sensor's operational limits under certain conditions. Furthermore, since different soil moisture sensors have different engineering designs, circuits, and technology that handle soil temperature and/or soil thermal conductivity vs. dielectric properties and $\theta_{\mathrm{v}}$ relationships differently, different soil moisture sensors may be influenced differently in measuring $\theta_{\mathrm{v}}$ of the same soil medium.

Very limited number of studies investigated the soil temperature effect(s) on different soil properties that, in turn, influence sensor response to changes in $\theta_{\mathrm{v}}$ through field and laboratory research and modeling (Or and Wraith, 1999; Baumhardt et al., 2000; Western and Seyfried, 2005; Saito et al., 2009). Pepin et al. (1995) investigated the TDR measurement errors of the apparent dielectric constant of distilled water and different soils (sand, loam, and peat) associated with soil temperature variations. In all cases, they found that the apparent dielectric constant decreased with increasing temperatures. The temperature dependence of the dielectric constant of water in a soil matrix was lower than that of bulk water, which was more pronounced for finetextured and organic soils than for loamy soil. They also observed that with higher $\theta_{\mathrm{v}}$ in the same soil, the temperature effect on the dielectric constant was more pronounced. In examining the interactions between soil surface area, $\theta_{\mathrm{v}}$, and soil temperature, Wraith and Or (1999) found that finer soils and/or soils with lower $\theta_{\mathrm{v}}$ favored an increase in bulk dielectric constant with increasing temperature, and that coarse-textured soils and/or soils with high $\theta_{\mathrm{v}}$ favored a decrease in bulk dielectric constant under the same temperature conditions. This observation can be explained through the competing effects of temperature on bulk dielectric constant of soil-water. The dielectric constant of bulk soil-water decreases with increased soil temperature, while that of bound water is presumed to increase with temperature. Hence, the relative proportions of bulk vs. bound water controls the aggregated temperature response for a given combination of soil and soil-water. 
Seyfried and Murdock (2001) suspended six water content reflectometers (WCR) simultaneously in air and subjected them to temperature changes from $-5^{\circ} \mathrm{C}$ to $45^{\circ} \mathrm{C}$ to investigate the response of the sensor electronics to temperature changes independent of potential soil medium effects. Temperature had a minor effect on the sensor response in air. However, when the sensors are installed in the soil, the sensor response was significantly affected by the temperature and this effect increased in absolute value with the $\theta_{\mathrm{v}}$. In addition, the effect of temperature on sensor response was significantly different for different soils tested. Persson and Berndtsson (1998) quantified temperature dependence of the apparent dielectric constant and electrical conductivity in wet soils by using an automated TDR system in sandy, clay, and organic soils. They confirmed the findings of Pepin et al. (1995) that change in apparent dielectric constant with temperature was lower in fine-textured soils and also found that a high concentration of electrolytes (high EC) in combination with fine-textured soils can lead to positive temperature dependence (i.e., $\theta_{\mathrm{v}}$ increases with increase in temperature). They also showed that the temperature effect on bulk electrical conductivity was independent of soil texture; and if high accuracy for $\theta_{\mathrm{v}}$ measurement is needed, the temperature dependence of electrical conductivity needs to be measured specifically.

The aforementioned sensor performance studies indicate that the same soil moisture sensor can perform differently in different soil-water environments, which require calibration for local soil conditions to establish and/or enhance the accuracy of $\theta_{\mathrm{v}}$ measurements. Also, because soil moisture sensors are evolving rapidly with newer sensors or the same type of sensors that have improved or different engineering features continually being released to the market, scientific evaluations of sensors in different soil types are justified to provide information to the users that can be useful in practical applications. Even if most of the sensors can be categorized as TDR- or FDR-type sensors, the engineering design, circuitry, and other manufacturing features can change significantly from one sensor to another even under the same category. For example, two FDR-type sensors that are made by different manufacturers may perform differently and the known performance of one FDR-type sensor may not be applicable to another FDRtype sensor that was designed and manufactured by a different company. This alone is an important justification to continue to evaluate soil moisture sensors under different soil conditions. Also, a single study may not be able to investigate all soil moisture sensors that are available in the market in all soil types. Thus, a collection of numerous studies that investigate and quantify the performance of various types of sensors in different soil textures can provide a unique database and information that can collectively form a rich source that can provide invaluable guidance and information to the users in practical applications. Furthermore, research projects that evaluate the performance of the same sensor with different installation angle or orientation in the soil are rare. Finally, the effect of soil temperature on different soil moisture sensors' response can be considerably or significantly different for different soils, which justifies the need for investigating the response of different soil moisture sensors to soil temperature. The objectives of this research were to: (i) quantify the performance of various TDR- and FDRtype soil moisture sensors in two different soils with substantially different soil properties (saturated hydraulic conductivity, particle size distribution, water holding capacity, etc.) and develop calibration parameters that can be used in similar soil textures, (ii) investigate/quantify the soil temperature influence on sensor performance in different $\theta_{v}$ ranges in two soil types, and (iii) quantify the repeatability of the sensor performance. The null hypothesis of the research was that the sensor-measured and neutron probe-measured $\theta_{\mathrm{v}}$ values are not different and that soil temperature does not influence the sensor performance when measuring $\theta_{\mathrm{v}}$.

\section{Materials ANd Methods}

The sensors evaluated in this research were 5TE and 10HS soil moisture sensors from Decagon Devices, Inc. (Pullman, Wash.); SM150 from Delta-T Devices Ltd. (Cambridge, UK); CS616 Water Content Reflectometer from Campbell Scientific, Inc. (Logan, Utah); CS620 HydroSense Soil Water Measurement System from Campbell Scientific, Inc.; and Field Scout ${ }^{\mathrm{TM}}$ TDR300 from Spectrum Technologies, Inc. (Aurora, Ill.). Generally, all of these sensors can be classified into two categories as TDR (TDR300, CS620, and CS616) and FDR [5TE, 10HS, and SM150 (Delta-T Devices, 2013, 2014)], which essentially has the same operational principles as capacitance probes. The TDR300 sensor takes readings in two different modes based on the clay content of the soil. The user has two options: (i) if the soil medium does not have high clay content (i.e., $<27 \%$ ), then the TDR300 Standard Mode should be selected for the measurements; (ii) if the soil has more than $27 \%$ clay content, then the user should select TDR300 High Clay Mode. Both modes have internal calibration equations embedded into the TDR300 memory. In this research, the performance of the TDR300 sensor was measured for both modes. The performance of all sensors was evaluated against a calibrated neutron attenuation probe Troxler ${ }^{\circledR}$ model 4302 Depth Moisture Gauge (Research Triangle Park, N.C.) in each soil. Some of the characteristics of soil moisture sensors evaluated are presented in table 1. In each soil lysimeter, only one sensor of each sensor type was used for time-series data collection, which results in a single-domain data collection (e.g., no replication of a given sensor type), which could present a shortcoming in statistical analyses. However, this is a common process in these types of experiments and it is a very difficult task to utilize multiple (three or more) sensors of the same type of sensors to generate time series data in the same soil from the multiple same type of sensors to analyze the replicated (multi-domain) $\theta_{\mathrm{v}}$ data and analyze the standard deviation. This is especially very difficult in laboratory experiments. Nevertheless, the time series data from a given type of sensor in different soil types can still provide invaluable and valid performance data. In this 
Table 1. Soil Moisture Sensor Specifications.

\begin{tabular}{|c|c|c|c|c|c|c|}
\hline Sensor & $5 \mathrm{TE}^{\circledR}$ & $10 \mathrm{HS}^{\circledR}$ & $\mathrm{SM} 150^{\circledR}$ & TDR300 $^{\circledR}$ & $\mathrm{CS} 616^{\circledR}$ & HydroSense $^{\circledR}$ (CS620) \\
\hline $\mathrm{PL}^{[\mathrm{a}]}(\mathrm{cm})$ & 5.0 & 10 & 5.0 & $3.75-20$ & 30 & 20 \\
\hline Accuracy & $\begin{array}{c} \pm 3 \% \text { vol } \\
(<10 \mathrm{dS} / \mathrm{m})\end{array}$ & $\begin{array}{c} \pm 3 \% \text { vol } \\
(<10 \mathrm{dS} / \mathrm{m})\end{array}$ & $\begin{array}{c} \pm 3 \% \text { vol } \\
\mathrm{NA}^{[\mathrm{b}]}\end{array}$ & $\begin{array}{l} \pm 3 \% \text { vol } \\
(<2 \mathrm{dS} / \mathrm{m})\end{array}$ & $\begin{array}{l} \pm 2.5 \% \mathrm{vol} \\
(<0.5 \mathrm{dS} / \mathrm{m})\end{array}$ & $\begin{array}{l} \pm 3 \% \text { vol } \\
(<2 \mathrm{dS} / \mathrm{m})\end{array}$ \\
\hline Resolution & $0.08 \mathrm{~m}^{3} / \mathrm{m}^{3}$ & $0.08 \mathrm{~m}^{3} / \mathrm{m}^{3}$ & NA & $0.1 \mathrm{~m}^{3} / \mathrm{m}^{3}$ & $>0.1 \mathrm{~m}^{3} / \mathrm{m}^{3}$ & $1.0 \mathrm{~m}^{3} / \mathrm{m}^{3}$ \\
\hline $\mathrm{ROI}^{[\mathrm{c}]}(\mathrm{cm})$ & 5.0 & 5.0 & 5.0 & 3.0 & 5.0 & 3.0 \\
\hline Datalogger & EM50 & EM50 & DL6 & NA & CR10X & NA \\
\hline Capability & $\begin{array}{c}\text { Measures EC, } \\
\theta_{\mathrm{v}} \text {, and } \\
\text { temperature }\end{array}$ & $\begin{array}{l}\text { Minimal salinity } \\
\text { and textural effects } \\
\text { in most soils }\end{array}$ & $\begin{array}{c}\text { Good temperature } \\
\text { and salinity } \\
\text { stability }\end{array}$ & $\begin{array}{l}\text { Portable, easy to } \\
\text { change the length } \\
\text { of rods }\end{array}$ & $\begin{array}{l}\text { High accuracy for } \\
\text { long-term } \\
\text { unattended } \\
\text { monitoring }\end{array}$ & Portable, handheld display \\
\hline
\end{tabular}

[a] Probe length.

[b] NA: not available.

[c] Radius of influence.

research, while only one sensor was used for a given sensor type, the wetting-drying cycle experiments were repeated twice to increase the amount of time series and repeated data measured using each type of sensor and to quantify and evaluate the repeatability of the measurements for each sensor. The $\theta_{\mathrm{v}}$ measurements from all sensors were taken on an hourly basis. The neutron probe measurements were taken manually on selected days. The sensor $\theta_{\mathrm{v}}$ outputs were correlated to the neutron probe-measured $\theta_{\mathrm{v}}$ on the days and times when the neutron probe measurements were taken.

\section{EXPERIMENTAL SETUP AND SOIL TYPES}

Two different soil (silt loam and loamy sand) taken from production fields near Clay Center and Central City, Nebraska, respectively, were used in the research. The loamy sand soil obtained from Central City is deep, moderately well-drained, and moderately permeable soil with $0-2 \%$ slope. The soil obtained from Clay Center is a Hastings silt loam, which is a well-drained upland soil (fine, montmorillonitic, mesic Udic Argiustoll) with 0-1\% slope. The pressure plate-measured field capacity and permanent wilting point values for silt loam soil are 0.34 and $0.125 \mathrm{~m}^{3} / \mathrm{m}^{3}$, respectively; and for loamy sand, the field capacity is $0.19 \mathrm{~m}^{3} / \mathrm{m}^{3}$ and the wilting point is $0.049 \mathrm{~m}^{3} / \mathrm{m}^{3}$. Some of the laboratory-measured chemical, physical, and hydraulic properties for both soils (from soil samples obtained from both soil lysimeters) are presented in table 2 .

The experimental setup and procedures used in this research were based on procedures presented in Irmak and Haman (2001) and Irmak and Irmak (2005). Soil drying cycle experiments were conducted in a greenhouse research facility. Two cylindrical poly lysimeters $1.6 \mathrm{~m}$ deep and $0.71 \mathrm{~m}$ in diameter were constructed and used (fig. 1). A drainage porous pipe in a circular shape was placed at the bottom of the lysimeters and connected to a drainage/outlet pipe to drain the excess soil water. The outlet pipe was fitted with a control valve for controlling drainage out of the lysimeter when/if needed. At the bottom of the lysimeters a $17.5 \mathrm{~cm}$ thick gravel layer was established above the porous pipe. Above the gravel, a $7.5 \mathrm{~cm}$ thick silica sand (play sand) layer was established. The gravel and sand layers at the lysimeter bed decreased the total water potential so that the soil-water would drain freely from the bottom of the soil to the drainage pipe (Irmak and Irmak, 2005). Soils obtained from the fields at Clay Center and Central City were added to each lysimeter in small increments in the same order that the soil layers were removed from the field and packed. A tamp was used to pack down the soil every $15 \mathrm{~cm}$ to ensure the bulk density of the lysimeter soil was close to that of the natural soil under field conditions. One aluminum neutron attenuation probe access tube was installed in the center of each lysimeter to measure $\theta_{\mathrm{v}}$ and used as the reference for other soil moisture sensors.

\section{SOIL Moisture SENSOR InSTALlation AND MEASUREMENTS}

Soil moisture measurements were taken during two drying cycles for each soil. In addition to performance analyses and developing calibration equations, the primary objective for conducting two drying cycle experiments with each sensor and soil was to evaluate the repeatability of the sensor performance. Sensors were installed at $20-30 \mathrm{~cm}$ depth from the soil surface. All sensors were installed vertically, except for the CS616 sensors for which horizontal and vertical installations were made for a pair of CS616 sensors in each lysimeter and the performance of the vertical and horizontal installations were measured separately in each soil. Because of possible electromagnetic interference among the sensors, adequate distance between the sensors was

Table 2. Measured chemical (ppm), physical, and hydraulic properties of experimental soils.

\begin{tabular}{|c|c|c|c|c|c|c|c|c|c|c|c|c|c|}
\hline Soil Type & $\mathrm{pH}$ & $\mathrm{N}$ & $\mathrm{P}$ & K & $\begin{array}{c}\mathrm{Ca} \\
(\mathrm{ppm})\end{array}$ & $\mathrm{Mg}$ & $\mathrm{Na}$ & $\mathrm{Zn}$ & $\mathrm{Fe}$ & $\mathrm{Mn}$ & $\mathrm{Cu}$ & CEC & SAR \\
\hline Silt loam & 5.8 & 25.7 & 33 & 528 & 1950 & 321 & 45 & 2.5 & 64.8 & 12.4 & 0.5 & 19.0 & 0.83 \\
\hline Loamy sand & 6.4 & 12.3 & 14 & 172 & 1140 & 206 & 57 & 0.7 & 32.7 & 3.7 & 0.4 & 8.1 & 1.09 \\
\hline Soil Type & $\begin{array}{c}\text { Sand } \\
(\%)\end{array}$ & $\begin{array}{c}\text { Clay } \\
(\%)\end{array}$ & $\begin{array}{l}\text { Silt } \\
(\%)\end{array}$ & & & $\begin{array}{c}\mathrm{FC} \\
\mathrm{m}^{3} / \mathrm{m}^{3}\end{array}$ & $\begin{array}{l}\text { PWP } \\
\mathrm{m}^{3} / \mathrm{m}^{3}\end{array}$ & & $\begin{array}{c}\theta_{\mathrm{s}} \\
\mathrm{m}^{3} / \mathrm{m}^{3}\end{array}$ & $\begin{array}{c}\rho_{\mathrm{b}} \\
\mathrm{g} \cdot \mathrm{cm}^{-3}\end{array}$ & & $\begin{array}{c}\text { Comp. } \\
\mathrm{kPa}\end{array}$ & $\begin{array}{c}\mathrm{EC} \\
\mathrm{dS} / \mathrm{m}\end{array}$ \\
\hline Silt loam & 31 & 17 & 52 & & & 0.34 & 0.13 & & 0.49 & 1.35 & & 0.90 & 0.35 \\
\hline Loamy sand & 77 & 7.0 & 16 & & & 0.19 & 0.05 & & 0.42 & 1.54 & & 0.96 & 0.13 \\
\hline
\end{tabular}

[a] OMC: organic matter content; FC: field capacity; PWP: permanent wilting point; $\theta_{\mathrm{s}}$ : saturation point; $\rho_{\mathrm{b}}$ : bulk density; EC: electrical conductivity; Comp.: Compaction. 

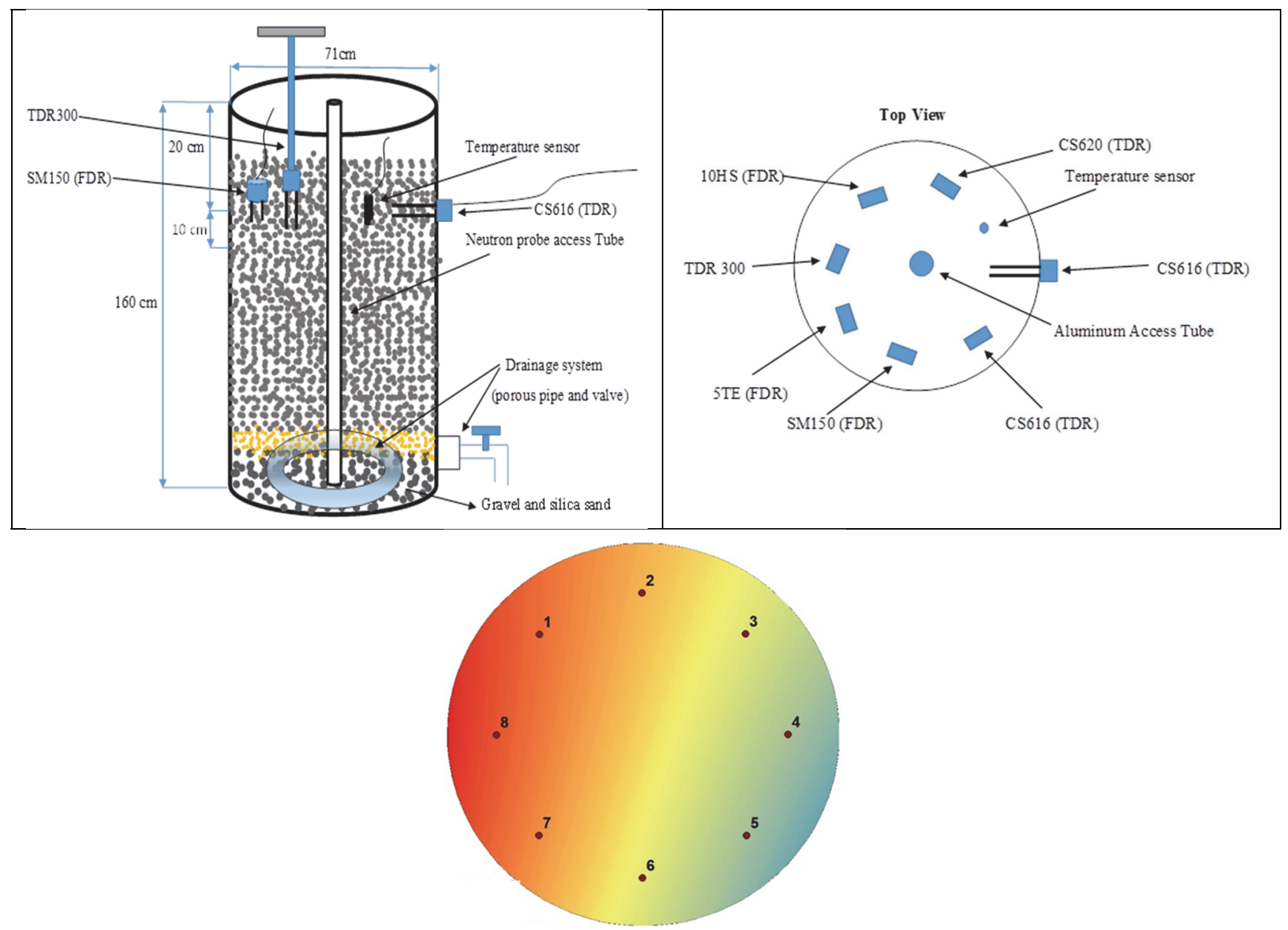

Figure 1. Schematic representation of the soil lysimeters and orientation of soil moisture sensors (left and upper right) and a top view of orientation of eight soil temperature sensors used in the research.

maintained based on the sensing volume (area of influence) of each sensor. In the horizontal installation of the CS616 sensor, the sensor head remained outside of the lysimeter and only sensor rods were inserted into the lysimeter horizontally (Irmak and Irmak, 2005; Irmak and Haman, 2001). The CS616 sensor head does not have any parts that actually measure $\theta_{\mathrm{v}}$ as it only houses the electronics/circuits. Even though the lysimeters are not made of steel or aluminum and the lysimeter wall was $3 \mathrm{~mm}$ thick; the sensor rod that was inserted horizontally was protected with $3 \mathrm{~mm}$ thick rubber seals that were placed around the sensor rods where it was in contact with the lysimeter wall to prevent any potential for the sensor rods to be in contact/interference with the lysimeter wall as an additional precaution. After all of the sensors and the neutron probe access tubes were installed, a drip irrigation tube was installed on the soil surface in a cylindrical orientation that covered the soil surface to ensure uniform water application and soil wetting. The procedures for the two wetting-drying cycles were essentially the same. Soil lysimeters were wetted to their near-saturation points (49\% vol for silt loam soil and $42 \%$ vol for loamy sand) and the wetting cycle was repeated two to three times for each soil to ensure uniform wetting before data collection began. The measurements with all sensors were taken as the soils in both lysimeters were naturally drying down to low moisture contents near permanent wilting points $(13 \%$ vol for silt loam soil and 5\% vol for loamy sand soil). Since the neutron probe was used as a reference for performance evaluations for all other soil moisture sensors, it is critical to obtain calibration curves for this method to assess the accuracy of the neutron probe itself. The calibration curves for the neutron probe that was used in this research were developed for both soils using a gravimetric method (figs. 2a and $2 b$ ). Figures $2 \mathrm{a}$ and $2 \mathrm{~b}$ represent the gravimetric methoddetermined volumetric soil-water content (Y-axis) and neutron-probe measured volumetric soil-water content (Xaxis) (factory calibration water content values).

\section{Soil Temperature EfFect On Sensor Performance}

After completing the experiments (cycles) I and II for soil moisture sensor performance analysis, additional experiments were carried out to quantify the impact of soil temperature on soil moisture sensor performance. Eight soil temperature sensors (Model 200TS, Irrometer, Co., Riverside, Calif.), which consist of a precision thermistor with a high resolution $\left( \pm 0.2^{\circ} \mathrm{C}\right)$, encased in epoxy potting compound for direct burial applications, and a resistive device that have fast response to changes in temperature were installed vertically at the same depth as the soil moisture sensors in a circular pattern to continuously 


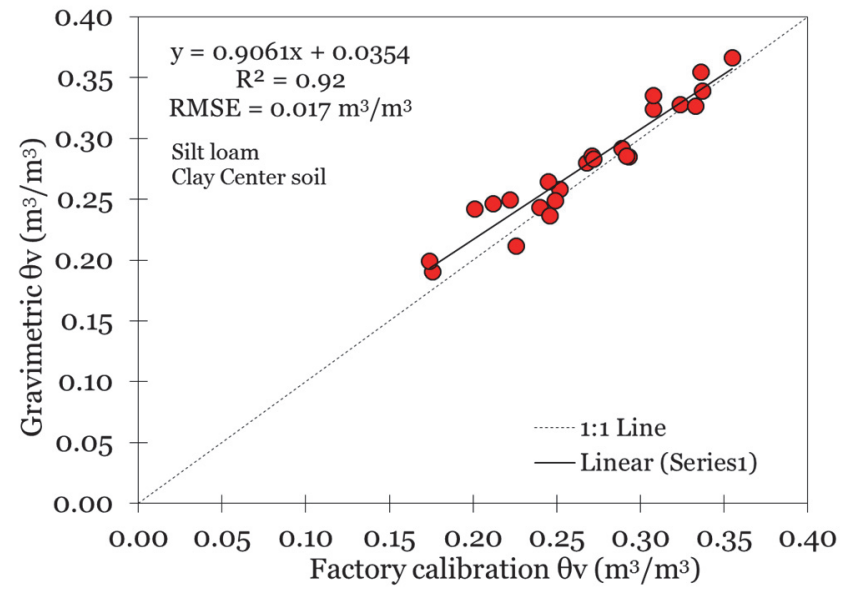

(a)

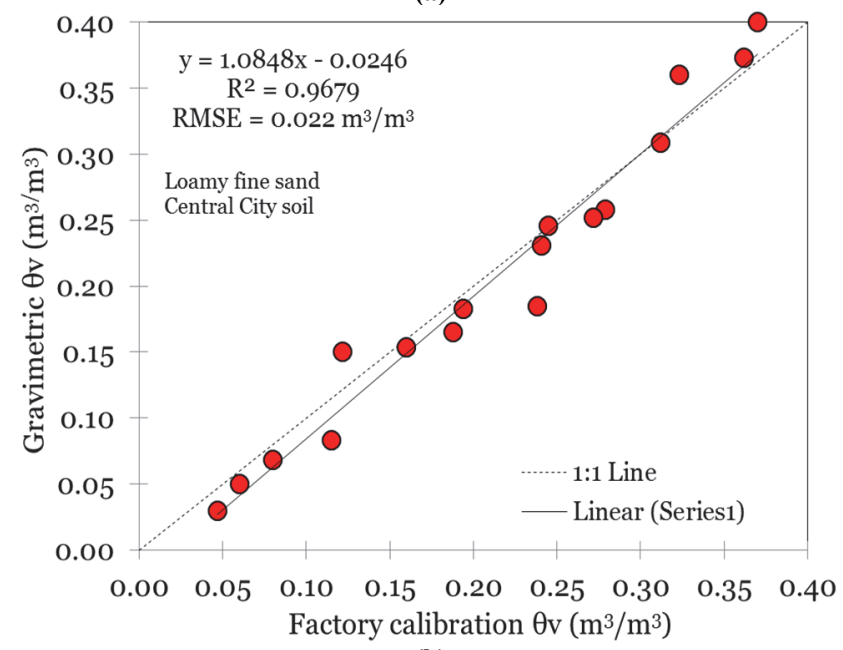

(b)

Figure 2. Calibration data and equations for the neutron attenuation gauge (probe) in silt loam soil (a) at Clay Center, Neb., and in a fine loamy sand soil (b) at Central City, Neb. RMSE: root mean squared error between gravimetric sampling-determined volumetric soil-water content $\left(\theta_{v}\right)$ and neutron probe-measured $\theta_{v}$.

monitor soil temperature as well as its spatial distribution in the soil in each lysimeter. The soil temperature sensor has dimensions of $1.2 \mathrm{~cm}$ in diameter and $5.7 \mathrm{~cm}$ in length with a maximum operating temperature of $150^{\circ} \mathrm{C}$. The temperature sensors were connected to the Watermark Monitor datalogger (Model 900M, Irrometer, Co., Riverside, Calif.) to record the data on an hourly basis. To analyze the soil temperature effect on sensor performance, three heat lamps per lysimeter were installed on the soil surface. Heat lamps were installed approximately $20 \mathrm{~cm}$ above the soil surface to ensure that the sensor's aboveground components were not directly heated and affected by the lamps. Furthermore, as an additional precaution, any aboveground sensor components were covered with aluminum foil to avoid any potential heat damage to the sensor components. Thus, during this process, only the soil medium was heated up to a specified temperature. $\theta_{\mathrm{v}}$ measurements were taken during the normal (around $24^{\circ} \mathrm{C}$ ) and above normal (heating period during which the soil temperature increased from the normal value up to $46^{\circ} \mathrm{C}-47^{\circ} \mathrm{C}$ ) temperature range. Increase in soil temperature vs. sensor-measured $\theta_{\mathrm{v}}$ response were measured and compared to the neutron probe-measured $\theta_{\mathrm{v}}$, which is not impacted by soil temperature. The performance of each sensor in measuring $\theta_{\mathrm{v}}$ under high temperature conditions (temperatures above $24^{\circ} \mathrm{C}$ during the heating period) was analyzed and comparisons were made with respect to their performances under normal temperature conditions (temperatures below $24^{\circ} \mathrm{C}$, or when the soils are not being heated).

\section{Statistical AnAlyses}

The sensor performance analyses in terms of accuracy in measuring $\theta_{\mathrm{v}}$ were conducted using the manufacturers' factory calibration parameters. The soil-specific calibration equations and regression (calibration) parameters (slope and intercept) were measured for each sensor in both soils using the neutron probe-measured $\theta_{\mathrm{v}}$ data as the reference. The t-test, RMSE, and coefficient of determination $\left(\mathrm{R}^{2}\right)$ were used to evaluate sensor performance relative to neutron probe-measured $\theta_{\mathrm{v}}$ data. The null hypothesis was that the mean difference between the sensor-measured and neutron probe-measured $\theta_{\mathrm{v}}$ is zero $(\mu=0)$. Any potential statistical significant differences between any sensor and the neutron probe-measured $\theta_{\mathrm{v}}$ data were identified at the $5 \%$ significance level. The RMSE was calculated as:

$$
R M S E=\sqrt{\frac{\sum_{i=1}^{n}\left(E_{i}-M_{i}\right)^{2}}{n}}
$$

where $M_{i}$ is the reading from the sensors, $E_{i}$ is the corresponding calibrated neutron probe $\theta_{\mathrm{v}}$ value, and $n$ is the number of observations.

\section{RESUlTS AND DISCUSSION \\ Temporal Trends in SOIL WATER CONTENT}

Temporal trends and magnitudes of measured $\theta_{\mathrm{v}}$ by all sensors are presented in figures $3 \mathrm{a}$ and $3 \mathrm{~b}$. Large discrepancies were observed in sensor performance with respect to neutron probe measurements due to performance differences among the sensors, as well as differences in measurement radius (area of influence). During the first drying cycle in the silt loam soil (fig. 3a), the initial $\theta_{\mathrm{v}}$ readings from all sensors differed (some of them substantially) from the neutron probe-measured $\theta_{\mathrm{v}}$ they generally followed a decreasing trend as the soil-water evaporated. Also, large differences were observed between sensor-measured and neutron probe-measured $\theta_{\mathrm{v}}$ on the same day due to poor performance of some of the sensors. Some sensors exhibited increased $\theta_{\mathrm{v}}$ values after exhibiting gradually decreasing trends even through no water was added to the lysimeters after the drying cycle began and there was no upward water flux. This phenomenon could be attributed to the error (noise) of the individual sensors. The neutron probe-measured $\theta_{\mathrm{v}}$ was the lowest, ranging from 0.42 to $0.22 \mathrm{~m}^{3} / \mathrm{m}^{3}$. The CS616 sensor installed in a vertical orientation $(\mathrm{CS} 616 \mathrm{~V})$ had the highest $\theta_{\mathrm{v}}$ readings, ranging from 0.70 to $0.58 \mathrm{~m}^{3} / \mathrm{m}^{3}$. Depending on the soil-water status, the average measurement radius for the neutron probe is 
about $16 \mathrm{~cm}$, which surpasses the measurement radius of all other sensors. Thus, during the early stages of the experiment when the soil was near-saturation, in both soils (figs. 3a and $3 b$ ), readings from most of the sensors were much higher than neutron probe readings during the early stages of the experiment; however, at the following stage, when some of the soil-water had evaporated and some of the soil water had moved downward due to potential gradient, the overall $\theta_{\mathrm{v}}$ decreased at 20 to $30 \mathrm{~cm}$ depth, which resulted in the extended measurement radius of the neutron probe. The neutron probe's radius of influence increases with drying soils due to less hydrogen (in water molecules) that collide with the neutrons. In this case, the neutron probe averages the $\theta_{\mathrm{v}}$ in a relatively larger radius (e.g., $\sim 20 \mathrm{~cm}$ ), thus producing lower readings, while the other sensors have smaller measurement volume, and the soil in this volume was further from the soil surface and less effected by evaporation, resulting in higher readings by the other sensors. Nevertheless, most of the bounced neutrons from the hydrogen atoms in the soil-water molecules captured by
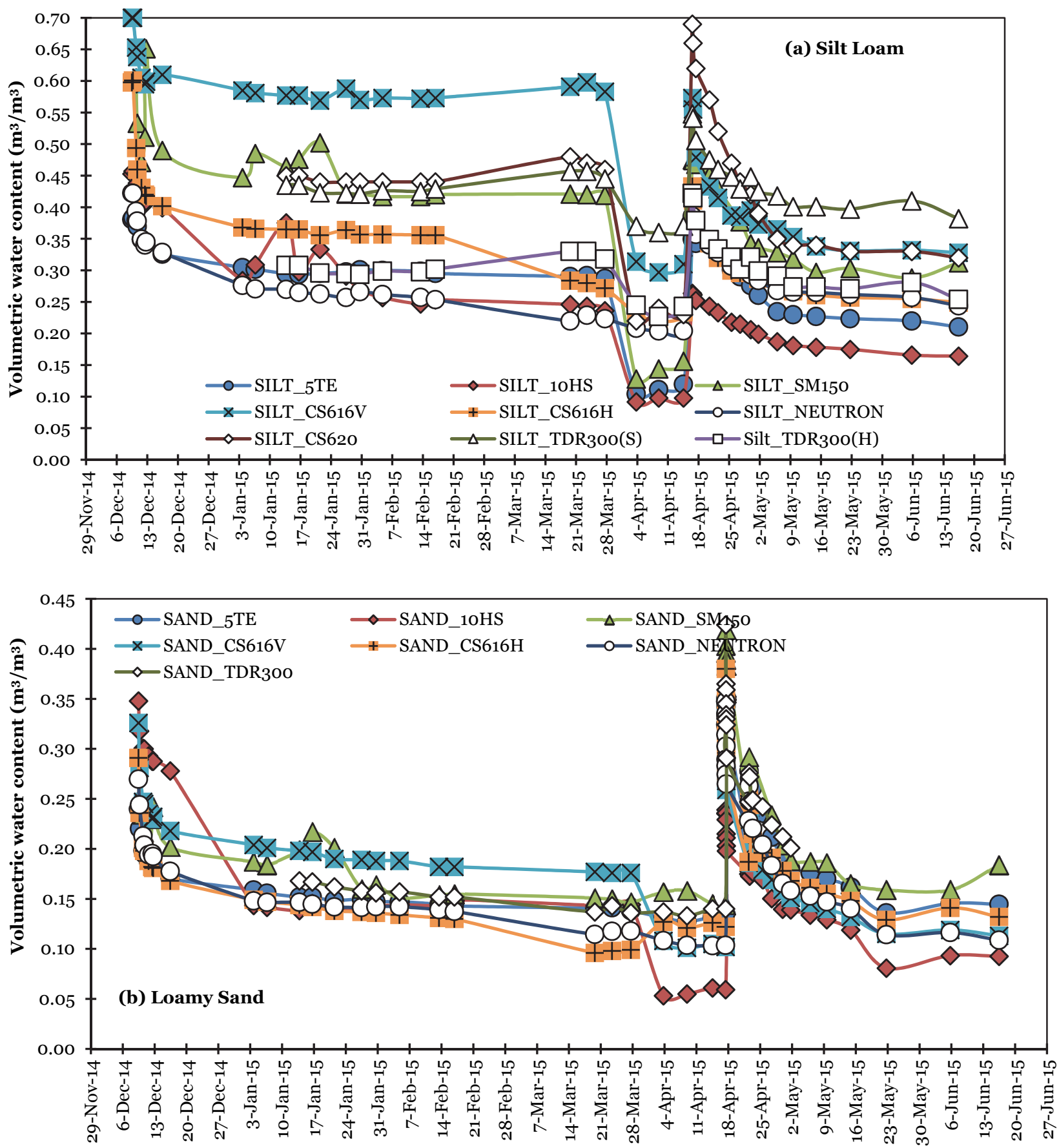

Figure 3. Temporal distribution of volumetric soil-water content $\left(\theta_{v}\right)$ for two wetting-drying cycle experiments (cycle I and II) for all soil moisture sensors in the silt loam (a) and sandy loam (b) soils. 
the neutron probe should be within the $16 \mathrm{~cm}$ radius (or less) due to moist conditions, which makes the effective measurement volume of the neutron probe relatively closer to the other sensors' measurement volume. Temporal distributions of $\theta_{\mathrm{v}}$ in the loamy sand are presented in figure $3 b$. The difference between figure $3 a$ and $3 b$ is that the readings from different sensors are closer to each other than those observed in the silt loam soil, although some large differences in sensor performance were still observed. The readings from the neutron probe were not the lowest, because the water holding capacity for loamy sand was not as high as that of silt loam. Thus, the water infiltrates in vertical direction more quickly in loamy sand than in silt loam, thus water is distributed uniformly in a short time and that the neutron probe readings would be closer to the readings by other sensors.

\section{SoIL MoISTURe Sensor Performance EXPERIMENT (CYCLE) I}

To more closely evaluate the sensor performance in different $\theta_{\mathrm{v}}$ ranges, soil-water range was divided into high and low $\theta_{\mathrm{v}}$ ranges in both soils in both cycles. The division point was the trigger point for irrigation (usually suggested at $35-45 \%$ of available water holding capacity), which were $21.5 \mathrm{~m}^{3} / \mathrm{m}^{3}$ for silt loam and $14.1 \mathrm{~m}^{3} / \mathrm{m}^{3}$ for loamy sand soil. To include enough data points to investigate the performance of sensors in the low $\theta_{\mathrm{v}}$ range in the silt loam, we adjusted the dividing point to a slightly higher value (26 $\mathrm{m}^{3} / \mathrm{m}^{3}$ for silt loam and $17 \mathrm{~m}^{3} / \mathrm{m}^{3}$ for loamy sand). These values were used only as examples and the proper management allowable depletion values in practical applications should be determined based on the soil and crop conditions in a given location. The sensor performance results from all sensors in both soils in experiment (cycle) I are presented in figure 4 (a through n) and the performance statistics of each sensor in low and high $\theta_{\mathrm{v}}$ ranges are presented in table 3 . Substantial variations in sensor performances were observed in both soils. The $\theta_{\mathrm{v}}$ readings from all sensors were significantly different $(P<$ $0.05)$ than the neutron probe readings for both soils in all $\theta_{\mathrm{v}}$ ranges (table 3 ). The pooled data RMSE ranged from $0.048 \mathrm{~m}^{3} / \mathrm{m}^{3}$ for 5TE to $0.287 \mathrm{~m}^{3} / \mathrm{m}^{3}$ for CS616 (V) in the silt loam soil; while they ranged from $0.013 \mathrm{~m}^{3} / \mathrm{m}^{3}$ for
CS616 $(\mathrm{H})$ to $0.056 \mathrm{~m}^{3} / \mathrm{m}^{3}$ for $10 \mathrm{HS}$ in the sandy loam soil. In the low $\theta_{\mathrm{v}}$ range in the silt loam soil, although the performance of the 5TE sensor was strong with an RMSE of $0.071 \mathrm{~m}^{3} / \mathrm{m}^{3}$, three other sensors [10HS, CS616 (H) and TDR300 (High Clay)] exhibited better performance and $10 \mathrm{HS}$ had the best performance. Based on the pooled data RMSE, the 5TE performed the best in the silt loam soil in experiment I. In the loamy sand, CS616 $(\mathrm{H})$ had the best performance in both low and high $\theta_{\mathrm{v}}$ ranges and the 5TE had the second-best performance among all sensors. All sensors (except 10HS) performed better in loamy sand than in silt loam based on the RMSE and $\mathrm{R}^{2}$ values.

\section{SoIl Moisture Sensor Performance Experiment (CYCLE) II}

Sensor performance results from all sensors in both soils in experiment (cycle) II are presented in figure 4 (a through n) and the performance statistics are presented in table 4 . When considering the pooled $t$-test values, the overall performance of all sensors was significantly different $(P<0.05)$ from the neutron probe measurements. When comparing RMSE values in table 4 with those observed from experiment I, all sensors had better performances in experiment II. In the silt loam and high $\theta_{\mathrm{v}}$ conditions, the CS616 (H) sensor had the lowest RMSE and the CS620 sensor had the highest value. In silt loam soil and low $\theta_{\mathrm{v}}$ range, the performance of the CS616 $(\mathrm{H})$ sensor was also the best. In contrast, the overall performance of 5TE was the best in silt loam in experiment I. In the loamy sand, CS616 (H) had the best performance in the high $\theta_{\mathrm{v}}$ range and the CS616 (V) sensor had the best performance in the low $\theta_{\mathrm{v}}$ range. Overall, CS616 (V) performed the best in the loamy sand; however, in experiment I, CS616 (H) had the best performance. Overall, in experiment II, SM150, 5TE, and CS616 (H) performed better in silt loam soil based on the pooled RMSE values while the rest of the sensors performed better in the loamy sand.

\section{POOLED DATA FROM EXPERIMENTS I AND II}

Sensor performance results of all sensors in both soils based on pooled data from experiments (cycles) I and II are presented in figure 4 (a through $\mathrm{n}$ ) and the performance statistics are presented in table 5 . The pooled RMSE values for all sensors ranged from $0.041 \mathrm{~m}^{3} / \mathrm{m}^{3}$ for $5 \mathrm{TE}$ to

Table 3. Performance statistics of all sensors for experiment (cycle) I in both soils. ${ }^{\text {[a] }}$

\begin{tabular}{|c|c|c|c|c|c|c|c|c|}
\hline \multirow[b]{2}{*}{ Sensor } & \multirow[b]{2}{*}{ Soil } & \multicolumn{3}{|c|}{$t$-test $t_{(0.025, \mathrm{n}-1)}$} & \multicolumn{3}{|c|}{$\operatorname{RMSE}\left(\mathrm{m}^{3} / \mathrm{m}^{3}\right)$} & \multirow[b]{2}{*}{$\mathrm{R}^{2}$} \\
\hline & & $\mathrm{HWC}^{[1]}$ & $\mathrm{LWC}^{[2]}$ & Pooled & HWC & LWC & Pooled & \\
\hline \multirow[t]{2}{*}{ SM150 } & Silt loam & $14.33_{(2.179)}$ & $6.96_{(2.306)}$ & $13.83_{(2.08)}$ & 0.195 & 0.152 & 0.179 & 0.59 \\
\hline & Loamy sand & $6.2_{(2.12)}$ & $12.1_{(2.447)}$ & $9.04_{(2.069)}$ & 0.035 & 0.041 & 0.037 & 0.79 \\
\hline \multirow[t]{2}{*}{$5 \mathrm{TE}$} & Silt loam & $5.64_{(2.145)}$ & $8.56_{(2.306)}$ & $6.64_{(2.069)}$ & 0.026 & 0.071 & 0.048 & 0.61 \\
\hline & Loamy sand & $6.3_{(2.11)}$ & $18.4_{(2.447)}$ & $7.77_{(2.064)}$ & 0.012 & 0.025 & 0.017 & 0.98 \\
\hline \multirow[t]{2}{*}{$10 \mathrm{HS}$} & Silt loam & $6.36_{(2.145)}$ & $2.98_{(2.306)}$ & $6.45_{(2.069)}$ & 0.055 & 0.065 & 0.059 & 0.82 \\
\hline & Loamy sand & $4.04_{(2.11)}$ & $8.94_{(2.447)}$ & $5.46_{(2.064)}$ & 0.061 & 0.040 & 0.056 & 0.89 \\
\hline \multirow[t]{2}{*}{ CS616 (V) } & Silt loam & $46_{(2.145)}$ & $6.42_{(2.306)}$ & $17.92_{(2.069)}$ & 0.286 & 0.288 & 0.287 & 0.49 \\
\hline & Loamy sand & $27.5_{(2.11)}$ & $2.25_{(2.447)}$ & $10.68_{(2.064)}$ & 0.039 & 0.046 & 0.044 & 0.90 \\
\hline \multirow[t]{2}{*}{ CS616 (H) } & Silt loam & $11.99_{(2.145)}$ & $5.12_{(2.306)}$ & $10.9_{(2.069)}$ & 0.105 & 0.069 & 0.093 & 0.93 \\
\hline & Loamy sand & $6.25_{(2.11)}$ & $29.11_{(2.447)}$ & $7.74_{(2.064)}$ & 0.009 & 0.019 & 0.013 & 0.92 \\
\hline \multirow[t]{2}{*}{ TDR300 (S) } & Silt loam & $63.9_{(2.776)}$ & $17.22_{(2.306)}$ & $23.6_{(2.16)}$ & 0.163 & 0.189 & 0.18 & 0.26 \\
\hline & Loamy sand & $13.1_{(2.365)}$ & $10.86_{(2.447)}$ & $11.1_{(2.145)}$ & 0.051 & 0.029 & 0.023 & 0.85 \\
\hline TDR300 (H) & Silt loam & $13.85_{(2.776)}$ & $5.26_{(2.306)}$ & $6.57_{(2.16)}$ & 0.036 & 0.067 & 0.058 & 0.27 \\
\hline CS620 & Loamy sand & $96.71_{(2.776)}$ & $4.57_{(2.306)}$ & $7.62_{(2.16)}$ & 0.179 & 0.178 & 0.178 & 0.48 \\
\hline
\end{tabular}

[a] HWC: High water content range; LWC: Low water content range. RMSE: Root mean squared error. 
Table 4. Performance statistics of all sensors in experiment (cycle) II in both soils. ${ }^{\text {[a] }}$

\begin{tabular}{|c|c|c|c|c|c|c|c|c|}
\hline \multirow[b]{2}{*}{ Sensor } & \multirow[b]{2}{*}{ Soil } & \multicolumn{3}{|c|}{$t-\operatorname{test}\left(t_{0.025, n-1}\right)$} & \multicolumn{3}{|c|}{$\operatorname{RMSE}\left(\mathrm{m}^{3} / \mathrm{m}^{3}\right)$} & \multirow[b]{2}{*}{$\mathrm{R}^{2}$} \\
\hline & & HWC & LWC & Pooled & HWC & LWC & Pooled & \\
\hline \multirow[t]{2}{*}{ SM150 } & Silt loam & $8.84_{(2.201)}$ & $2.66_{(12.71)}$ & $9.12_{(2.16)}$ & 0.078 & 0.053 & 0.074 & 0.95 \\
\hline & Loamy sand & $7.67_{(2.131)}$ & $5.15_{(4.303)}$ & $8.86_{(2.101)}$ & 0.064 & 0.056 & 0.063 & 0.94 \\
\hline \multirow[t]{2}{*}{$5 \mathrm{TE}$} & Silt loam & $5.91_{(2.179)}$ & $19.2_{(12.71)}$ & $6.94_{(2.145)}$ & 0.026 & 0.035 & 0.027 & 0.94 \\
\hline & Loamy sand & $10.1_{(2.101)}$ & $7.11_{(4.303)}$ & $11.42_{(2.08)}$ & 0.033 & 0.030 & 0.032 & 0.94 \\
\hline \multirow[t]{2}{*}{$10 \mathrm{HS}$} & Silt loam & $27.4_{(2.179)}$ & $14.9_{(12.71)}$ & $29.95_{(2.145)}$ & 0.095 & 0.086 & 0.094 & 0.98 \\
\hline & Loamy sand & $8.51_{(2.101)}$ & $4.82_{(4.303)}$ & $8.36_{(2.08)}$ & 0.063 & 0.025 & 0.059 & 0.96 \\
\hline \multirow[t]{2}{*}{ CS616 (V) } & Silt loam & $9.85_{(2.179)}$ & $17.3_{(12.71)}$ & $10.75_{(2.145)}$ & 0.110 & 0.080 & 0.106 & 0.93 \\
\hline & Loamy sand & $5.13_{(2.101)}$ & $2.58_{(4.303)}$ & $5.02_{(2.08)}$ & 0.016 & 0.003 & 0.015 & 0.97 \\
\hline \multirow[t]{2}{*}{ CS616 (H) } & Silt loam & $3.19_{(2.179)}$ & $2.38_{(12.71)}$ & $3.25_{(2.145)}$ & 0.018 & 0.004 & 0.017 & 0.96 \\
\hline & Loamy sand & $5.52_{(2.101)}$ & $6.8_{(4.303)}$ & $6.54_{(2.08)}$ & 0.015 & 0.021 & 0.016 & 0.96 \\
\hline \multirow[t]{2}{*}{ TDR300 (S) } & Silt loam & $41.9_{(2.179)}$ & $19.7_{(12.71)}$ & $47.2_{(2.145)}$ & 0.144 & 0.146 & 0.144 & 0.96 \\
\hline & Loamy sand & $10.2_{(2.131)}$ & NA & $10.2_{(2.131)}$ & 0.041 & NA & 0.041 & 0.95 \\
\hline TDR300 H) & Silt loam & $5.17_{(2.179)}$ & $2.47_{(12.71)}$ & $5.84_{(2.145)}$ & 0.021 & 0.018 & 0.020 & 0.96 \\
\hline CS620 & Loamy sand & $6.88_{(2.179)}$ & $46.48_{(12.71)}$ & $6.89_{(2.145)}$ & 0.181 & 0.075 & 0.171 & 0.99 \\
\hline
\end{tabular}

[a] HWC: High water content range; LWC: Low water content range. RMSE: Root mean squared error $\left(\mathrm{m}^{3} / \mathrm{m}^{3}\right)$.

$0.234 \mathrm{~m}^{3} / \mathrm{m}^{3}$ for CS616 (V) in the silt loam soil, while in the loamy sand, the pooled RMSE values ranged from $0.014 \mathrm{~m}^{3} / \mathrm{m}^{3}$ for CS616 $(\mathrm{H})$ to $0.057 \mathrm{~m}^{3} / \mathrm{m}^{3}$ for 10HS. In the silt loam soil and high $\theta_{\mathrm{v}}$ range, the 5TE and TDR300 (High Clay) sensors had the lowest RMSE $\left(0.026 \mathrm{~m}^{3} / \mathrm{m}^{3}\right)$ while the highest RMSE $\left(0.223 \mathrm{~m}^{3} / \mathrm{m}^{3}\right)$ was observed for CS616 (V). In the same soil at low $\theta_{\mathrm{v}}$ range, the performance of the TDR300 (High Clay) sensor was the best with an RMSE of $0.061 \mathrm{~m}^{3} / \mathrm{m}^{3}$. Overall, the performance of 5TE was the best in silt loam soil while TDR300 (High Clay), CS616 (H), and 10HS were ranked as second, third, and fourth best overall.

In the loamy sand, CS616 $(\mathrm{H})$ had the best performance in both high and low $\theta_{\mathrm{v}}$ with a low pooled RMSE of 0.014 $\mathrm{m}^{3} / \mathrm{m}^{3}$. When comparing the performance of individual sensors between different $\theta_{\mathrm{v}}$ ranges in both soils, the performance of all the sensors was better in the high $\theta_{v}$ range than in the low $\theta_{\mathrm{v}}$ range. When comparing the performance of TDR300 (Standard) and TDR300 (High Clay) in silt loam soil, the TDR300 (High Clay) performed better in silt loam soil under our experimental conditions, although the manufacturer suggests that High Clay mode would provide more accurate results for soils with high clay content (i.e., $>27 \%$ ). The Hastings silt loam soil that was used in the experiments had $17 \%$ clay content, indicating the importance of soil-specific calibration of sensors for accurate quantification of $\theta_{\mathrm{v}}$.

\section{RePeatability of Sensor Performance}

One of the important advantages of conducting two experiments using the same procedures and sensors in the same environment is that the repeatability of sensor performance can be determined. One of the significant observations with all sensors was that all sensors responded to changes in soil moisture linearly, which indicate that the calibration equations measured in these experiments can be used to calibrate the sensors evaluated to increase their accuracy in same soils used in these experiments. However, the linearity or repeatability of some of the sensors showed variations between the soils and the repeatability also showed variations for the same sensor in the same soil between the experiments (comparing experiment I and II results in fig. 4). Repeatability was evaluated based on the distribution of the data around 1:1 line and the consistency of the direction of over- or underestimation between the experiments. For example, SM150 performed better in experiment II in silt loam soil with lower RMSE (fig. 4a) and had poor repeatability; however, it had good repeatability in loamy sand (fig. 4b). The repeatability for 5TE ranks one of the best among all sensors. In experiment I, the 10HS sensor overall overestimated in both soils, but it underestimated in both soils in experiment II with greater RMSE, indicating poor repeatability. The CS616 (V) and CS616 (H) had good repeatability in both soils. TDR300 had good repeatability in silt loam soil, but poor

Table 5. Performance statistics of all sensors in both soils for pooled (pooled from experiment I and II) data. ${ }^{\text {[a] }}$

\begin{tabular}{|c|c|c|c|c|c|c|c|}
\hline \multirow[b]{2}{*}{ Sensor } & \multirow[b]{2}{*}{ Soil } & \multicolumn{3}{|c|}{$t$-test $t_{(0.025, \mathrm{n}-1)}$} & \multicolumn{3}{|c|}{$\operatorname{RMSE}\left(\mathrm{m}^{3} / \mathrm{m}^{3}\right)$} \\
\hline & & $\mathrm{HWC}$ & LWC & Pooled & HWC & LWC & Pooled \\
\hline \multirow[t]{2}{*}{ SM150 } & Silt loam & $9.37_{(2.064)}$ & $6.22_{(2.228)}$ & $11.37_{(2.03)}$ & 0.151 & 0.139 & 0.147 \\
\hline & Loamy sand & $8.68_{(2.037)}$ & $10.8_{(2.262)}$ & $11.1_{(2.018)}$ & 0.051 & 0.046 & 0.050 \\
\hline \multirow[t]{2}{*}{$5 \mathrm{TE}$} & Silt loam & $8.27_{(2.052)}$ & $8.26_{(2.228)}$ & $8.33_{(2.024)}$ & 0.026 & 0.066 & 0.041 \\
\hline & Loamy sand & $8.49_{(2.028)}$ & $17.3_{(2.262)}$ & $11.14_{(2.013)}$ & 0.025 & 0.027 & 0.025 \\
\hline \multirow[t]{2}{*}{$10 \mathrm{HS}$} & Silt loam & $11.3_{(2.052)}$ & $3.97_{(2.228)}$ & $11.09_{(2.024)}$ & 0.076 & 0.070 & 0.074 \\
\hline & Loamy sand & $8.05_{(2.028)}$ & $8.73_{(2.262)}$ & $9.3_{(2.013)}$ & 0.062 & 0.037 & 0.057 \\
\hline \multirow[t]{2}{*}{ CS616 (V) } & Silt loam & $10.9_{(2.052)}$ & $5.74_{(2.228)}$ & $12.16_{(2.024)}$ & 0.223 & 0.262 & 0.234 \\
\hline & Loamy sand & $9.06_{(2.028)}$ & $2.19_{(2.262)}$ & $8.53_{(2.013)}$ & 0.034 & 0.033 & 0.034 \\
\hline \multirow[t]{2}{*}{ CS616 (H) } & Silt loam & $6.15_{(2.052)}$ & $4.25_{(2.228)}$ & $7.42_{(2.024)}$ & 0.078 & 0.062 & 0.074 \\
\hline & Loamy sand & $7.57_{(2.028)}$ & $20.7_{(2.262)}$ & $9.94_{(2.013)}$ & 0.012 & 0.020 & 0.014 \\
\hline \multirow[t]{2}{*}{ TDR300 (S) } & Silt loam & $45.0_{(2.11)}$ & $17.66_{(2.228)}$ & $31.6_{(2.048)}$ & 0.149 & 0.182 & 0.162 \\
\hline & Loamy sand & $9.53_{(2.069)}$ & $10.86_{(2.447)}$ & $11.77_{(2.042)}$ & 0.035 & 0.029 & 0.034 \\
\hline TDR300 (H) & Silt loam & $7.01_{(2.11)}$ & $4.92_{(2.228)}$ & $6.59_{(2.048)}$ & 0.026 & 0.061 & 0.043 \\
\hline CS620 & Loamy sand & $9.85_{(2.11)}$ & $4.84_{(2.228)}$ & $10.39_{(2.048)}$ & 0.181 & 0.164 & 0.175 \\
\hline
\end{tabular}

[a] HWC: High water content range; LWC: Low water content range. RMSE: Root mean squared error. 

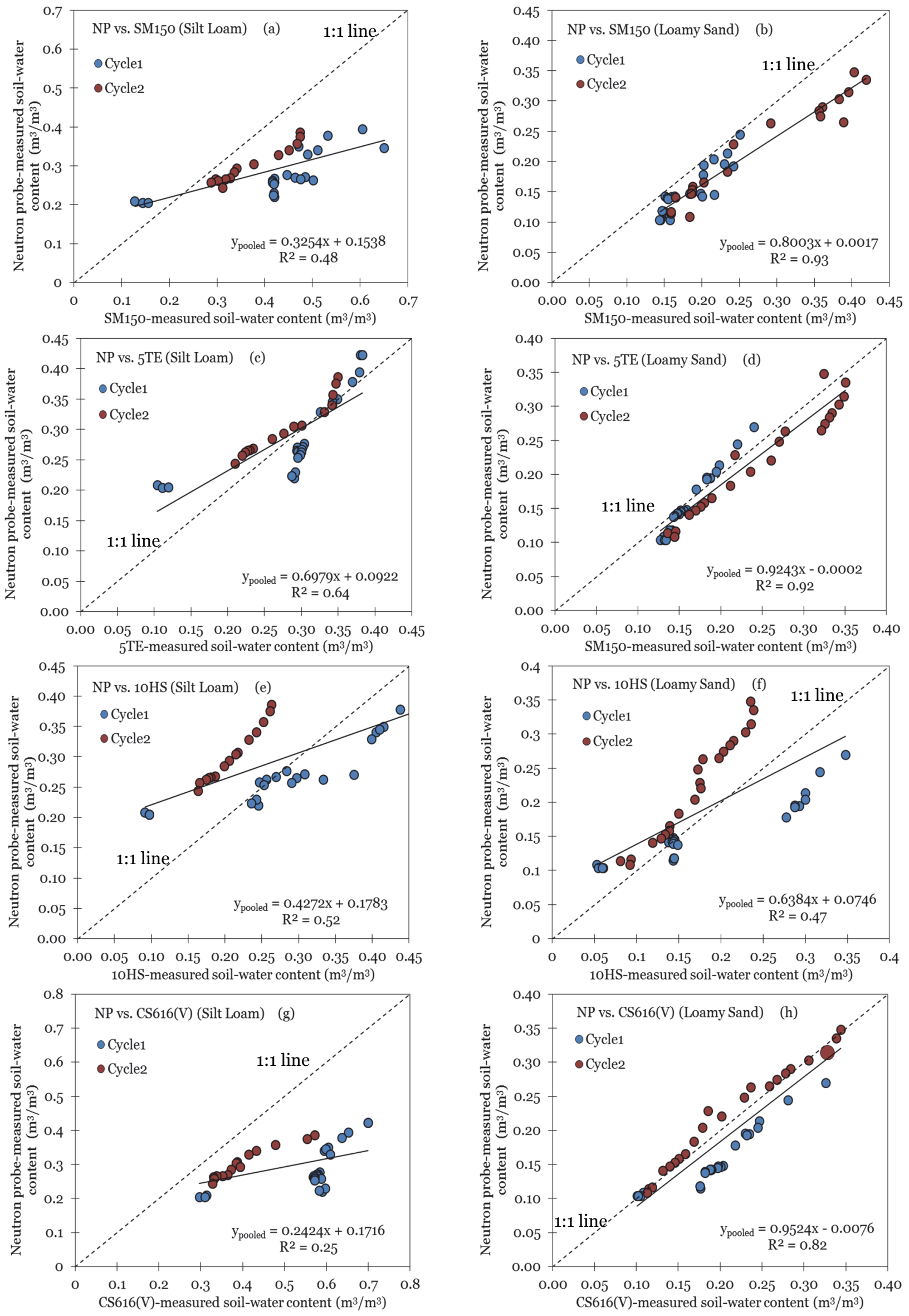

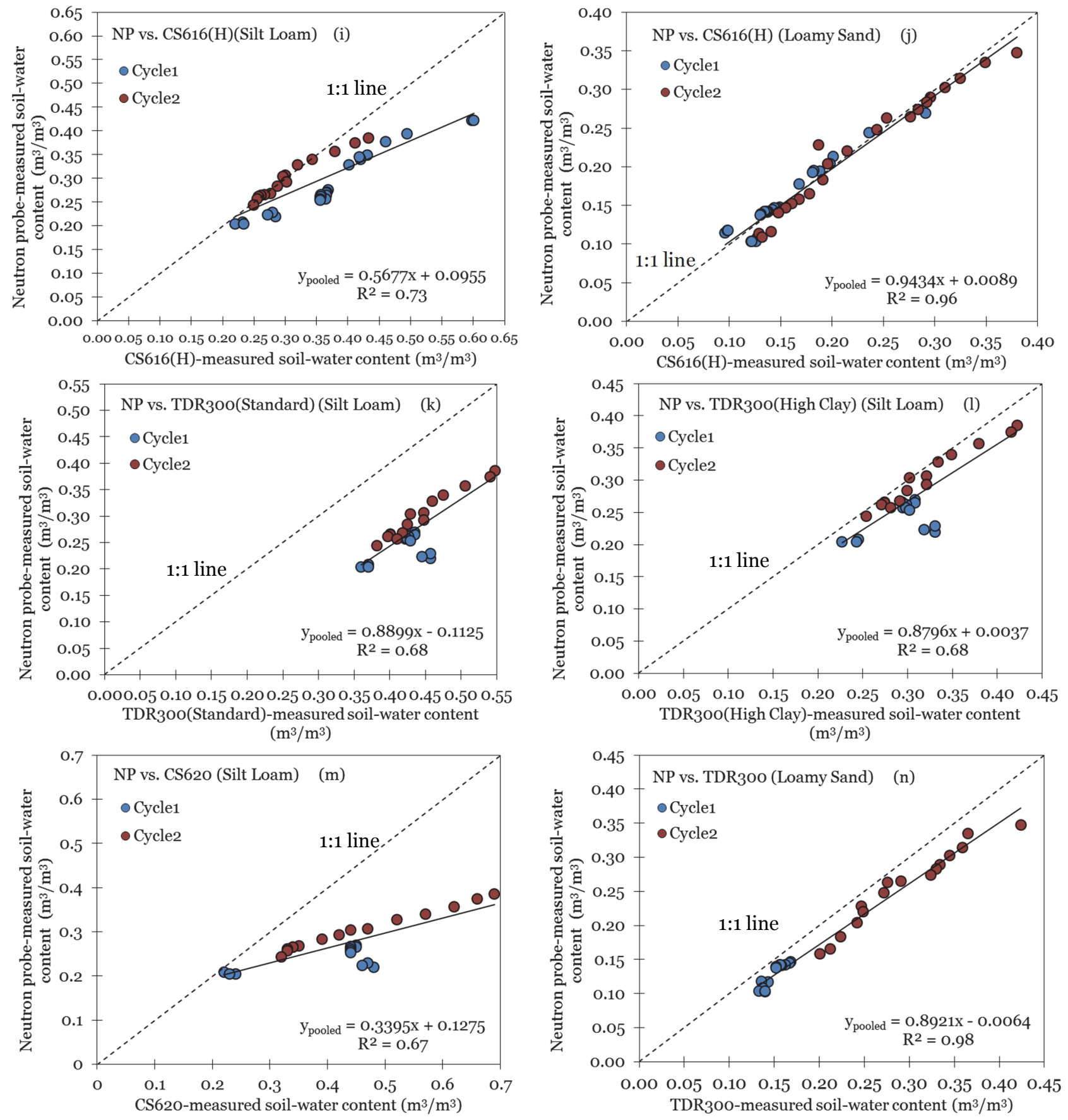

Figure 4 (a through $\mathbf{n}$ ). Linear regression between neutron probe- and sensor-measured volumetric soil-water content ( $\left.\theta_{\mathrm{v}}\right)$ in silt loam and loamy sand soils for all sensors for pooled data [combined experiments (cycles) I and II].

repeatability in loamy sand with High Clay Mode; while its repeatability was consistent with Standard Mode in loamy sand. The performance of CS620 was poor in both experiments in silt loam soil, but its repeatability was consistent.

\section{Soil Moisture Sensor Performance in Response to NORMAL AND HIGH TEMPERATURE RANGES}

In silt loam soil, some sensors responded to high vs. normal temperature ranges differently by over- or underestimating the neutron probe-measured $\theta_{\mathrm{v}}$ in the same soil. Also, the response of the same sensor to high vs. normal temperature differed between the soils. For example, the 10HS sensor overestimated in silt loam soil, while it underestimated in loamy sand soil within the high temperature range (table 6). All other sensors underestimated $\theta_{\mathrm{v}}$ in the high temperature range in both soils, but the degree of underestimation differed substantially for the same sensor between the soils as well as between the sensors within the same soil. The RMSE between sensor-measured $\theta_{\mathrm{v}}$ vs. neutron probemeasured $\theta_{\mathrm{v}}$ of the same sensor also differed substantially between the soils, indicating the impact of soil textural properties on sensor performance response to soil temperature change. For example, the RMSE values in silt 
Table 6. Error in soil moisture sensor performance under different temperature conditions ${ }^{[a]}$ for silt-loam and loamy sand soils.

\begin{tabular}{|c|c|c|}
\hline \multicolumn{3}{|c|}{ Silt loam } \\
\hline Sensor & $\begin{array}{l}\text { Soil Temp. } \\
\text { Range }\end{array}$ & $\begin{array}{l}\operatorname{RMSE}^{[\mathrm{b}]} \\
\left(\mathrm{m}^{3} / \mathrm{m}^{3}\right)\end{array}$ \\
\hline \multirow[t]{2}{*}{ SM150 } & High & 0.177 \\
\hline & Normal & 0.147 \\
\hline \multirow[t]{2}{*}{$5 \mathrm{TE}$} & High & 0.050 \\
\hline & Normal & 0.041 \\
\hline \multirow[t]{2}{*}{$10 \mathrm{HS}$} & High & 0.036 \\
\hline & Normal & 0.074 \\
\hline \multirow[t]{2}{*}{ CS616 (Vertical Installation) } & High & 0.350 \\
\hline & Normal & 0.234 \\
\hline \multirow[t]{2}{*}{ CS616 (Horizontal Installation) } & High & 0.136 \\
\hline & Normal & 0.074 \\
\hline \multirow[t]{2}{*}{ TDR300 (Standard Mode) } & High & 0.233 \\
\hline & Normal & 0.162 \\
\hline \multirow[t]{2}{*}{ TDR300 (High Clay Mode) } & High & 0.107 \\
\hline & Normal & 0.043 \\
\hline \multirow[t]{2}{*}{ CS620 } & High & 0.238 \\
\hline & Normal & 0.175 \\
\hline \multicolumn{3}{|c|}{ Loamy sand } \\
\hline Sensor & $\begin{array}{c}\text { Soil Temp. } \\
\text { Range }\end{array}$ & $\begin{array}{l}\text { RMSE } \\
\left(\mathrm{m}^{3} / \mathrm{m}^{3}\right)\end{array}$ \\
\hline \multirow[t]{2}{*}{$\overline{\mathrm{SM} 150}$} & High & 0.026 \\
\hline & Normal & 0.050 \\
\hline \multirow[t]{2}{*}{$5 \mathrm{TE}$} & High & 0.017 \\
\hline & Normal & 0.025 \\
\hline \multirow[t]{2}{*}{$10 \mathrm{HS}$} & High & 0.051 \\
\hline & Normal & 0.057 \\
\hline \multirow[t]{2}{*}{ CS616 (Vertical Installation) } & High & 0.057 \\
\hline & Normal & 0.034 \\
\hline \multirow[t]{2}{*}{ CS616 (Horizontal Installation) } & High & 0.006 \\
\hline & Normal & 0.014 \\
\hline \multirow[t]{2}{*}{ TDR300 (Standard Mode) } & High & 0.021 \\
\hline & Normal & 0.034 \\
\hline
\end{tabular}

[a] Normal soil temperature range (below $24^{\circ} \mathrm{C}$ ) and high temperature range during the heating period (above $24^{\circ} \mathrm{C}$ ).

[b] RMSE: root mean squared error between sensor-measured $\theta_{v}$ and neutron probe-measured $\theta_{\mathrm{v}}\left(\mathrm{m}^{3} / \mathrm{m}^{3}\right)$.

loam soil for SM150, 5TE, 10HS, CS616 (V), CS616 (H), and TDR300 (S) were $0.177,0.05,0.036,0.35,0.136$, and $0.233 \mathrm{~m}^{3} / \mathrm{m}^{3}$, respectively; while they were $0.026,0.017$, $0.051,0.057,0.006$, and $0.021 \mathrm{~m}^{3} / \mathrm{m}^{3}$ in loamy sand for the same sensors, respectively (table 6). The largest RMSE $\left(0.35 \mathrm{~m}^{3} / \mathrm{m}^{3}\right)$ was observed with the CS616 vertical installation. This is attributed to the fact that with the vertical installation, the CS616 electrodes (rods) were in contact with a greater soil layer/soil area and, in turn, exposed to a greater area of increased soil temperature, thus creating a more pronounced impact of soil temperature on dielectric constant. For the same sensor with horizontal installation, the RMSE was only $0.136 \mathrm{~m}^{3} / \mathrm{m}^{3}$. Similarly, in loamy sand soil, the CS616 (V) had 9.5 times greater RMSE with vertical installation than horizontal installation $\left(0.057 \mathrm{~m}^{3} / \mathrm{m}^{3}\right.$ for vertical vs. $0.006 \mathrm{~m}^{3} / \mathrm{m}^{3}$ for horizontal). In general, the RMSE values for all sensors were smaller in loamy sand than in silt loam soil. The order of the RMSE values in terms of lowest to greatest impact of soil temperature on sensor performance (order from least sensitivity to greatest sensitivity) as compared to the normal temperature range in silt loam soil was: 5TE, TDR300 (High Clay Mode), CS616 (H), SM150, TDR300 (Standard Mode), CS620, and CS616 (V).
The impact of high soil temperature range on sensor performance also differed in the loamy sand soil. Unlike silt loam soil, the CS616 (H) had the least influence of soil temperature on its performance with a very small RMSE of $0.006 \mathrm{~m} / \mathrm{m}^{3}$ (table 6). The order of the RMSE values in terms of lowest to greatest impact of soil temperature on sensor performance in loamy sand soil was: 5TE, TDR300 (Standard Mode), SM150, 10HS and CS616 (V). Overall, in the silt loam soil, the difference in sensor-measured vs. neutron probe-measured $\theta_{\mathrm{v}}$ for all sensors under the high temperature range was lower than under normal temperatures conditions, which indicated that the temperature effect tends to increase the sensor-measured $\theta_{\mathrm{v}}$ in the silt loam soil. As shown by Wraith and Or (1999), in the silt loam soil, the proportion of bound water vs. bulk water is higher than that of loamy sand. Thus, when the temperature was high in silt loam soil, the dielectric constant of the bound water increases, while that of the bulk water decreases. Since there is a high proportion of bound water in the silt loam soil, the combination of temperature effects can be dominated by the effect on bound water. Therefore, the overall dielectric constant of bulk soil increases, which leads to the overestimation of $\theta_{\mathrm{v}}$ by most sensors in silt loam soil. In loamy sand, however, the proportion of bound water vs. bulk water is neither too low nor too high, causing a marginal temperature effect on the dielectric constant of bulk soil in this soil type as observed in current research.

The aforementioned results support the findings of Wraith and Or (1999), who observed that the measured bulk apparent dielectric constant (or permittivity) of soil $\left(\epsilon_{b}\right)$ increased substantially with increasing temperature for silt loam soil for all $\theta_{\mathrm{v}}$ ranges. For another silt loam soil and for an Oxisol, the measured $\epsilon_{b}$ increased with increasing temperature at relatively low $\theta_{\mathrm{v}}$, but decreased with increasing temperature at higher $\theta_{\mathrm{v}}$. For a sandy loam soil, they observed that the measured $\epsilon_{\mathrm{b}}$ decreased with increasing temperature for all $\theta_{\mathrm{v}}$ ranges. They hypothesized that TDR-based $\epsilon_{b}$ measurements are determined by interplay between two competing phenomena: (i) the reduction in the dielectric constant of bulk water with increased temperature, and (ii) the increase in TDR-based $\epsilon_{b}$ measurements with increased temperature due to the release of bound water. Thus, TDR-measured $\epsilon_{\mathrm{b}}$ is dependent on solid surface area and wetness. The increase in soil temperature can impose its effect on some of the sensors' performance in silt loam soil, while the influence of temperature on the same sensor(s) in loamy sand may not be as pronounced, as was observed in our research for some of the sensors. In other words, interactions between soil textural and hydraulic properties with the proxies of $\theta_{\mathrm{v}}$ (e.g., dielectric constant) can cause variations between the soils, which can influence the performance of the same sensor in different soils. This effect can be due to the changing of the dielectric constant of bulk soil under different temperature conditions, and may not be due to the operation of the sensors being influenced by the temperature. Seyfried and Murdock (2001) investigated soil moisture sensor calibration in four different soils under 

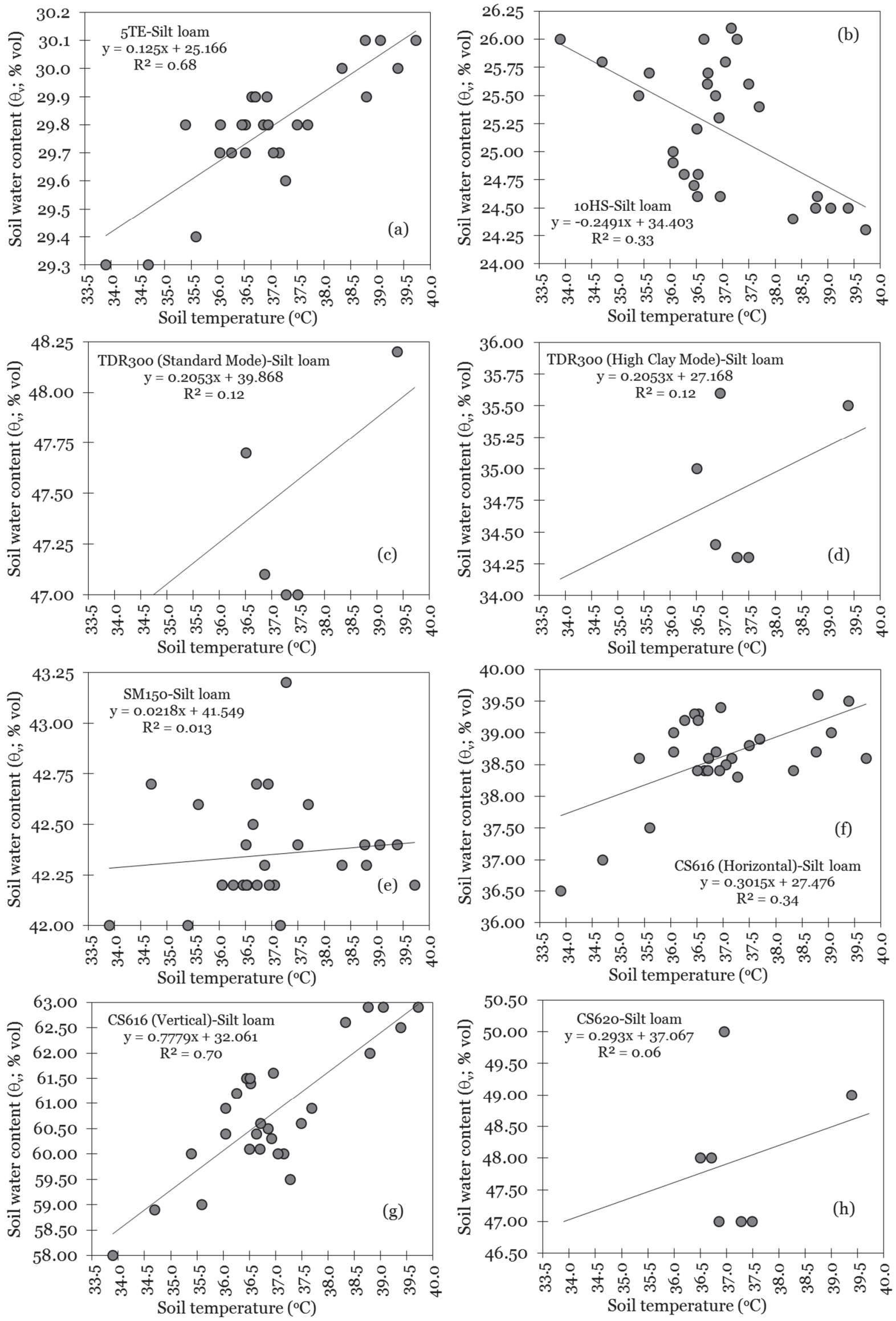

Figure 5. Relationship between soil temperature and soil water content for each sensor in silt loam soil. 

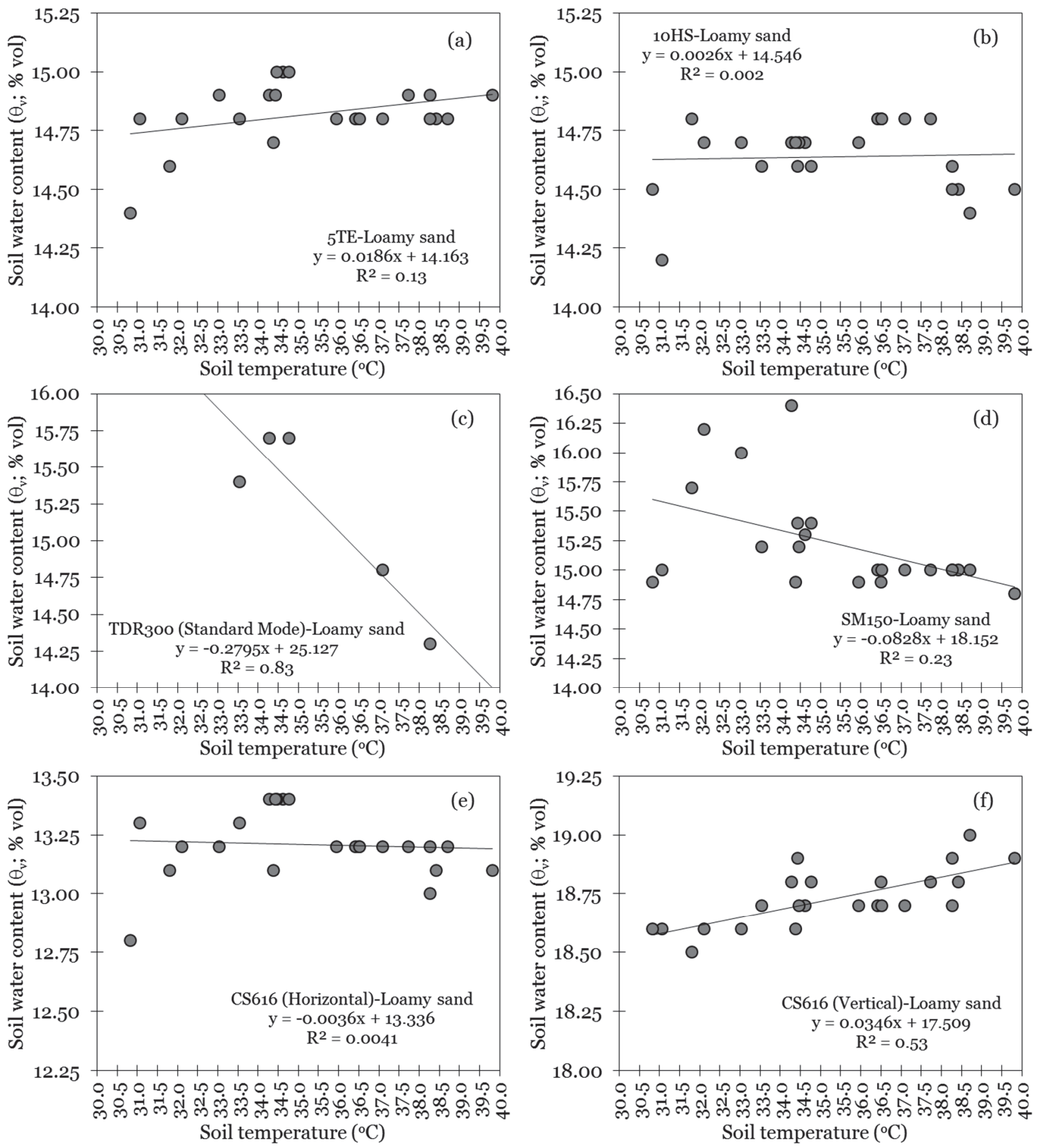

Figure 6. Relationship between soil temperature and soil water content for each sensor in loamy sand soil.

varying $\theta_{\mathrm{v}}$ across a $40^{\circ} \mathrm{C}$ temperature range and observed that sensor calibration was significantly $(P<0.05)$ different for each soil tested and that there was also a significant temperature response for all soils. They also found that the effect of temperature varied with $\theta_{\mathrm{v}}$ and soil type. Both the soil type and temperature sensitivities they observed were probably due to the relatively high electrical conductivity (EC) of the soils tested. They concluded that the water content reflectometry-type sensors (a derivative of TDR) were highly sensitive to soil temperature and that the degree of sensitivity depends on the initial $\theta_{\mathrm{v}}$ of the soil. The sensors were also especially sensitive to the EC of the soil; thus, soil EC and temperature should be accounted for when using these sensors.

\section{RELATIONSHIP BETWEEN SOIL-WATER CONTENT AND SoIl Temperature during the Heating Period}

To quantify the change in $\theta_{\mathrm{v}}$ response to soil temperature increase, regression analyses were conducted (fig. 5 for silt loam soil and fig. 6 for loamy sand) for each sensor during the heating period (temperatures above $24^{\circ} \mathrm{C}$ ). Also, a unit 
Table 7. Significance of slope and intercept at the $5 \%$ significance level and standard error of relationship between volumetric soil-water content $\left(\theta_{v}\right)$ and soil temperature, and change in $\theta_{v}\left(\mathrm{~m}^{3} / \mathrm{m}^{3}\right)$ in response to per $1^{\circ} \mathrm{C}$ increase in soil temperature for all sensors in silt loam and loamy sand soils. ${ }^{[a]}$

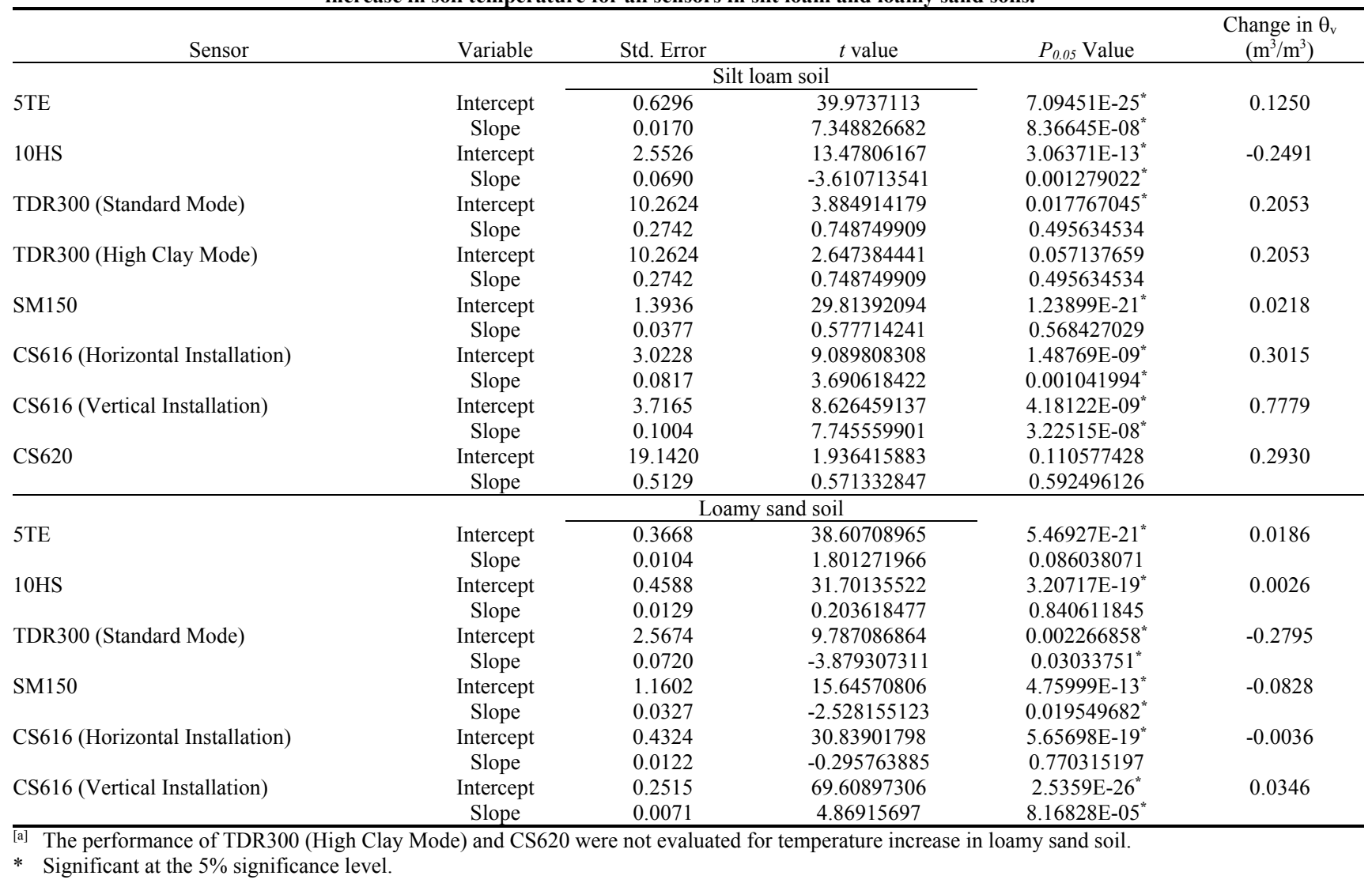

$\left(\mathrm{m}^{3} / \mathrm{m}^{3}\right)$ change in $\theta_{\mathrm{v}}$ for a $1^{\circ} \mathrm{C}$ increase in soil temperature was quantified for each sensor in both soils and the significance of slope and intercept in the relationships was quantified (table 7). The performance of TDR300 (High Clay Mode) and CS620 were not evaluated for temperature increase in loamy sand soil. The relationship between sensor performance and increase in soil temperature exhibited substantial variations between the sensors as well as for the same sensor within the same and between the soils. The majority of sensors exhibited a linear response (increase in $\theta_{\mathrm{v}}$ ) to increase in soil temperature. The 5TE showed a strong linear response $\left(\mathrm{R}^{2}=0.68\right)$ in silt loam soil (fig. 5a) and a much weaker response $\left(\mathrm{R}^{2}=0.13\right)$ in loamy sand (fig. 6a). Both the slope and the intercept of the relationships were significant (table 7). A $1{ }^{\circ} \mathrm{C}$ increase in soil temperature resulted in a $0.125 \mathrm{~m}^{3} / \mathrm{m}^{3}$ increase (beyond the intercept) in $\theta_{\mathrm{v}}$ in silt loam soil and a $0.02 \mathrm{~m}^{3} / \mathrm{m}^{3}$ increase in $\theta_{\mathrm{v}}$ in loamy sand. The response of the 10HS to temperature was negative with decreasing $\theta_{\mathrm{v}}$ with increasing temperature and the response was stronger in silt loam soil $\left(\mathrm{R}^{2}=0.33\right.$ ) (fig. $5 \mathrm{~b}$ ). The same sensor in loamy sand soil essentially did not respond to changes in soil temperature, which indicated the insensitivity of this sensor to soil temperature in loamy sand soil (fig. $6 \mathrm{~b}$ ). A $1{ }^{\circ} \mathrm{C}$ increase in temperature resulted in a $-0.2491 \mathrm{~m}^{3} / \mathrm{m}^{3}$ decrease in $\theta_{\mathrm{v}}$ in silt loam soil and a negligible $0.0026 \mathrm{~m}^{3} / \mathrm{m}^{3}$ increase in loamy sand soil.
The TDR300 with standard and high clay content operation modes responded similarly in silt loam soil (fig. $5 \mathrm{c}$ and d) with increasing trends. However, the same sensor with standard operation mode exhibited a decreasing trend in $\theta_{\mathrm{v}}$ with increasing temperature (fig. 6c). This sensor's sensitivity to soil temperature with standard operation mode in loamy sand soil was one of the greatest ( $4^{\text {th }}$ largest in terms of change in $\theta_{\mathrm{v}}$ against change in soil temperature) among all sensors investigated with $\mathrm{R}^{2}=0.83$, indicating that the $83 \%$ increase in $\theta_{\mathrm{v}}$ observed with this sensor during the heating period was due to the increase in soil temperature. $\mathrm{A} 1{ }^{\circ} \mathrm{C}$ increase in soil temperature resulted in exact increase in $\theta_{\mathrm{v}}$ of $0.2053 \mathrm{~m}^{3} / \mathrm{m}^{3}$ in silt loam soil with both standard and high clay content modes. However, a $1{ }^{\circ} \mathrm{C}$ increase in temperature resulted in a large $(-0.2795$ $\mathrm{m}^{3} / \mathrm{m}^{3}$ ) decrease in $\theta_{\mathrm{v}}$ in loamy sand. The SM150 was essentially insensitive to soil temperature in silt loam soil (fig. 5e) and marginally sensitive in loamy sand (fig. 6d), with $\mathrm{R}^{2}=0.23$ with a very small increase $\left(0.0218 \mathrm{~m}^{3} / \mathrm{m}^{3}\right.$ in silt loam soil) and decrease $\left(-0.0828 \mathrm{~m}^{3} / \mathrm{m}^{3}\right.$ in loamy sand) in $\theta_{\mathrm{v}}$ for a $1^{\circ} \mathrm{C}$ increase in temperature.

The CS616's sensitivity not only differed between the soils, but also by its installation orientation within each soil. In silt loam soil, the sensor was more sensitive $\left(\mathrm{R}^{2}=\right.$ 0.34 ) to soil temperature (fig. $5 \mathrm{f}$ ) and was essentially insensitive in loamy sand $\left(\mathrm{R}^{2}=0.0041\right)$ (fig. 6e) when installed horizontally. However, when it was installed vertically, its sensitivity increased significantly with $R^{2}=$ 
0.70 in silt loam (fig. $5 \mathrm{~g}$ ) and $\mathrm{R}^{2}=0.53$ in loamy sand (fig. 6f). The change in $\theta_{\mathrm{v}}$ with increasing temperature was much greater $\left(0.7779 \mathrm{~m}^{3} / \mathrm{m}^{3}\right.$, which was the greatest among all sensors) with vertical installation rather than horizontal $\left(0.3015 \mathrm{~m}^{3} / \mathrm{m}^{3}\right.$, the second greatest among all sensors $)$ in silt loam soil (table 7). The magnitude of change was much smaller in loamy sand $\left(-0.0036 \mathrm{~m}^{3} / \mathrm{m}^{3}\right.$ with horizontal installation and $0.0346 \mathrm{~m}^{3} / \mathrm{m}^{3}$ with vertical installation). The trade off with this sensor is in the accuracy in measuring $\theta_{\mathrm{v}}$, since CS616 provided much better performance in measuring $\theta_{\mathrm{v}}$ with respect to neutron probemeasured $\theta_{\mathrm{v}}$ in silt loam soil when installed horizontally rather than vertically. The CS620 was marginally sensitive to changes in soil temperature (fig. $5 \mathrm{~h}$ ) with $\mathrm{R}^{2}=0.06$ and a $1{ }^{\circ} \mathrm{C}$ increase in temperature resulting in a $0.293 \mathrm{~m}^{3} / \mathrm{m}^{3}$ change in $\theta_{\mathrm{v}}$ in silt loam soil.

The order of the magnitude of change in $\theta_{\mathrm{v}}$ in response to a $1{ }^{\circ} \mathrm{C}$ increase in soil temperature from the lowest to the greatest impact of soil temperature on sensor performance in silt loam soil was: SM150, 5TE, TDR300 (Standard Mode), 10HS, CS620, CS616 (H), and CS616 (V). The same order in loamy sand was: 10HS, CS616 (H), 5TE, CS616 (V), SM150, and TDR300 (Standard Mode). Overall, the intercept of the temperature vs. $\theta_{\mathrm{v}}$ was not significant $(P>0.05)$, except for TDR300 (High Clay Content Mode) and CS620 in silt loam soil. The slope was not significant for TDR300 (Standard Mode), TDR300 (High Clay Content Mode), SM150, or CS620. In loamy sand, the intercept of the regression lines was significant $(P<0.05)$ for all sensors. The slope, however, was not significant for only 5TE and CS616 horizontal installation. When the data from all sensors and soils are pooled (i.e., averaging all changes in $\theta_{\mathrm{v}}$ in response to increase in soil temperature in table 7), the average of change in $\theta_{\mathrm{v}}$ for a $1^{\circ} \mathrm{C}$ increase in soil temperature was $0.21 \mathrm{~m}^{3} / \mathrm{m}^{3}$ in silt loam soil and $-0.052 \mathrm{~m}^{3} / \mathrm{m}^{3}$ in loamy sand. When the sensor category (TDR vs. FDR) is considered in terms of sensitivity to soil temperature, in silt loam soil, the average change in $\theta_{\mathrm{v}}$ for a $1^{\circ} \mathrm{C}$ increase in soil temperature for the TDR-type sensors [TDR300 (S), TDR300 (HC), CS616 (H), CS616 (V), and CS620] was much greater $\left(0.3566 \mathrm{~m}^{3} / \mathrm{m}^{3}\right)$ than for the FDR-type sensors (5TE, 10HS, and SM150) $\left(-0.0341 \mathrm{~m}^{3} / \mathrm{m}^{3}\right)$. In loamy sand, similar observations were made as the TDR-type sensors had a greater change in $\theta_{\mathrm{v}}\left(-0.0828 \mathrm{~m}^{3} / \mathrm{m}^{3}\right)$ than the FDR-type sensors $\left(-0.02053 \mathrm{~m}^{3} / \mathrm{m}^{3}\right)$. When all TDR- and FDR-type sensors were pooled for both soils (the average of all TDRand FDR-type sensors in both soils), the average changes in $\theta_{\mathrm{v}}$ for a $1{ }^{\circ} \mathrm{C}$ increase in soil temperature for the TDR- and FDR-type sensors were 0.1918 and $-0.0273 \mathrm{~m}^{3} / \mathrm{m}^{3}$, respectively, indicating that overall, TDR-type sensors are more sensitive to soil temperature than FDR-type sensors in measuring $\theta_{\mathrm{v}}$ in silt loam and loamy sand soils for the sensors and soils investigated in this research.

\section{SUMMARY AND CONCLUSIONS}

The null hypothesis was rejected as the performances of all sensors were significantly different $(P<0.05)$ from the neutron probe-measured $\theta_{\mathrm{v}}$ and soil temperature had substantial influence on the performance of the sensors. The same sensor performed differently in the low and high $\theta_{\mathrm{v}}$ ranges and all sensors performed better in the high $\theta_{\mathrm{v}}$ range. Sensor $\theta_{v}$ measurement performance repeatability was consistent for most sensors, but the repeatability for some sensors showed variation between the experiments for the same soil and for the same experiment between the soils. These observed variations should be taken into account when selecting sensors for detailed and highly accurate $\theta_{\mathrm{v}}$ measurements. The response of the same sensor to high vs. normal soil temperature ranges differed between the soils and also within the same soil between the sensors. The RMSE values of the same sensor differed substantially between soils, indicating the impact of soil textural properties on sensor performance with increasing temperatures. The sensor installation orientation also affected the soil temperature impact on sensor performance (e.g., the CS616 sensor vertical installation had 9.5 times greater RMSE with vertical installation than horizontal. When the sensor category (TDR vs. FDR) is considered in terms of temperature effect, in silt loam soil the average change in $\theta_{\mathrm{v}}$ for a $1{ }^{\circ} \mathrm{C}$ increase in soil temperature for the TDR-type sensors [TDR300 (S), TDR300 (HC), CS616 $(\mathrm{H})$, CS616 (V), and CS620] was much greater $(0.3566$ $\left.\mathrm{m}^{3} / \mathrm{m}^{3}\right)$ than the average change in $\theta_{\mathrm{v}}$ for a $1^{\circ} \mathrm{C}$ increase in soil temperature for the FDR-type sensors (5TE, 10HS, and SM150), which was $-0.0341 \mathrm{~m}^{3} / \mathrm{m}^{3}$. In loamy sand, similar observations were made. Overall, TDR-type sensors are more sensitive to soil temperature than FDR-type sensors in measuring $\theta_{\mathrm{v}}$ in silt loam and loamy sand soils for the sensors and soils investigated in this research.

The results emphasize the critical importance of soilspecific calibrations of soil moisture sensors for accurate irrigation scheduling and monitoring soil moisture for various other applications. While some of the sensors performed differently between the two experiments, the pooled data calibration equations measured in this research are suggested to be applied to improve sensor performance in the same soils that were investigated in this research. The temperature impact(s) on soil moisture sensor performance should be considered for enhancing the accuracy of soil moisture measurements. Calibration equations measured in this research can provide practical and scientific data to enhance soil moisture measurements when using the same sensors and investigated.

\section{ACKNOWLEDGEMENT}

This project was partially supported by a grant obtained from the National Science Foundation (NSF) under the project number DBI-1331895. Dr. Suat Irmak acknowledges NSF and his current and former research team members who assisted in this project. This research is partially based upon work that is supported by the National Institute of Food and Agriculture, U.S. Department of Agriculture, Dr. Irmak's Hatch Project, under the Project Number NEB-21155. 


\section{REFERENCES}

Annan, A. P. (1977). Time domain reflectometry-air-gap problem for parallel wire transmission lines. Report of Activities, Part B. Geological Survey of Canada. Paper 77-1B, 59-62. https://doi.org/10.4095/102753

Baumhardt, R. L., Lascano, R. J., \& Evett, S. R. (2000). Soil material, temperature, and salinity effects on calibration of multisensor capacitance probes . SSSAJ, 64(6), 1940-1946. https://doi.org/10.2136/sssaj2000.6461940x

Chandler, D. G., Seyfried, M., Murdock, M., \& McNamara, J. P. (2004). Field calibration of water content reflectometers. SSSAJ, 68(5), 1501-1507. https://doi.org/10.2136/sssaj2004.1501

Dalton, F. N. (1992). Development of time-domain reflectometry for measuring soil water content and bulk soil electrical conductivity. In G. C. Topp, W. D. Reynolds, \& R. E. Green (Eds.), Advances in measurement of soil physical properties: Bringing theory into practice (pp. 143-167). Madison, WI: SSSA Special Publ. 30.

Dalton, F. N., Herkelrath, W. N., Rawlins, D. S., \& Rhoades, J. D. (1984). Time-domain reflectometry: Simultaneous measurement of soil water content and electrical conductivity with a single probe. Science, 224(4652), 989-990. https://doi.org/10.1126/science.224.4652.989

Davis, J. L., \& Chudobiak, W. J. (1975). In situ meter for measuring relative permittivity of soils. Geol. Survey Canada, 75(1A), 7579. https://doi.org/10.4095/104349

Delta-T. Devices. (2013). Em50/Em50R/Em50G Em50 series Data collection system operator's manual. Cambridge, U.K.

Delta-T. Devices. (2014). User manual for the SM150, 5TE, and 10HS soil moisture sensors. Cambridge, U.K.

Evett, S. R., \& Steiner, J. L. (1995). Precision of neutron scattering and capacitance type soil water content gauges from field calibration. SSSAJ, 59(4), 961-968. https://doi.org/10.2136/sssaj1995.03615995005900040001x

Fellner-Feldegg, H. (1969). Measurement of dielectrics in the time domain. J. of Physical Chemistry, 73(3), 616-623. https://doi.org/10.1021/j100723a023

Gong, Y., Cao, Q., \& Sun, Z. (2003). The effects of soil bulk density, clay content and temperature on soil water content measurement using time-domain reflectometry. Hydrol. Process., 17(18), 3601-3614. https://doi.org/10.1002/hyp.1358

Hillel, D. (1998). Environmental soil physics: Fundamentals, applications, and environmental considerations. London, U.K.: Academic Press.

Irmak, S., \& Irmak, A. (2005). Performance of frequency-domain reflectometer, capacitance, and psuedo-transit time-based soil water content probes in four coarse-textured soils. Appl. Eng. Agric., 21(6), 999-1008. https://doi.org/10.13031/2013.20035

Irmak, S., \& Z. Haman, D. (2001). Performance of the watermark. Granular matri x sensor in sandy soils. Appl. Eng. Agric., 17(6), 787-795. https://doi.org/10.13031/2013.6848

Irmak, S., Rees, J. M., Zoubek, G. L., VanDeWalle, B. S., Rathje, W. R., DeBuhr, R., ... Christiansen, A. P. (2010). Nebraska Agricultural Water Management Demonstration Network (NAWMDN): Integrating research and extension/outreach. Appl. Eng. Agric., 26(4), 599-613. https://doi.org/10.13031/2013.32066

Jabro, J. D., Stevensen, W. B., \& Iversen, W. M. (2017). Field performance of three real-time moisture sensors in sandy loam and clay loam soils . Arch. Agron. Soil Sci., 64(7), 930-938. https://doi.org/10.1080/03650340.2017.1393528

Kargas, G., \& Soulis, K. X. (2019). Performance evaluation of a recently developed soil water content, dielectric permittivity, and bulk electrical conductivity electromagnetic sensor. Agric. Water Manag., 213, 568-579.

https://doi.org/10.1016/j.agwat.2018.11.002
Knight, J. H. (1992). Sensitivity of time domain reflectometry measurements to lateral variations in soil water content. Water Resour. Res., 28(9), 2345-2352.

https://doi.org/10.1029/92WR00747

Leib, B. G., Jabro, J. D., \& Matthews, G. R. (2003). Field evaluation and performance comparison of soil moisture sensors. Soil Sci., 168(6), 396-408. https://doi.org/10.1097/01.ss.0000075285.87447.86

Miller, G. A., Farahani, H. J., Hassell, R. L., Khalilian, A., Adelberg, J. W., \& Wells, C. E. (2014). Field evaluation and performance of capacitance probes for automated drip irrigation of watermelons. Agric. Water Manag., 131(1), 124-134. https://doi.org/10.1016/j.agwat.2013.09.012

Ojo, E. R., Bullock, P. R., \& Fitzmaurice, J. (2014). Field performance of five soil moisture instruments in heavy clay soils. SSSAJ, 79(1), 20-29. https://doi.org/10.2136/sssaj2014.06.0250

Ojo, E. R., Bullock, P. R., Heureux, J., Powers, J., McNairn, H., \& Pacheco, A. (2015). Calibration and evaluation of a frequency domain reflectometry sensor for real-time soil moisture monitoring. Vadose Zone J., 14(3), 1-12. https://doi.org/10.2136/vzj2014.08.0114

Or, D., \& Wraith, J. M. (1999). Temperature effects on soil bulk dielectric permittivity measured by time domain reflectometry: A physical model. Water Resour. Res., 35(2), 371-383. https://doi.org/10.1029/1998WR900008

Paltineanu, I. C., \& Starr, J. L. (1997). Real-time soil water dynamics using multisensor capacitance probes: Laboratory calibration. SSSAJ, 61(6), 1576-1585. https://doi.org/10.2136/sssaj1997.03615995006100060006x

Pepin, S., Livingston, N. J., \& Hook, W. R. (1995). Temperaturedependent measurement errors in time domain reflectometry determinations of soil water. SSSAJ, 59(1), 38-43. https://doi.org/10.2136/sssaj1995.03615995005900010006x

Persson, M., \& Berndtsson, R. (1998). Texture and electrical conductivity effects on temperature dependency in time domain reflectometry. SSSAJ, 62(4), 887-893. https://doi.org/10.2136/sssaj1998.03615995006200040006x

Plauborg, F., Iversen, B. V., \& LÃ'rke, P. E. (2005). In situ comparison of three dielectric soil moisture sensors in drip irrigated sandy soils. Vadose Zone J., 4(4), 1037-1047. https://doi.org/10.2136/vzj2004.0138

Robinson, M., \& Dean, T. J. (1993). Measurement of near surface soil water content using a capacitance probe. Hydrol. Process., 7(1), 77-86. https://doi.org/10.1002/hyp.3360070108

Saito, T., Fujimaki, H., Yasuda, H., \& Inoue, M. (2009). Empirical temperature calibration of capacitance probes to measure soil water . SSSAJ, 73(6), 1931-1937. https://doi.org/10.2136/sssaj2008.0128

Seyfried, M. S., \& Murdock, M. D. (2001). Response of a new soil water sensor to variable soil, water content, and temperature. SSSAJ, 65(1), 28-34. https://doi.org/10.2136/sssaj2001.65128x

Soulis, K. X., Elmaloglou, S., \& Dercas, N. (2015). Investigating the effects of soil moisture sensors positioning and accuracy on soil moisture based drip irrigation scheduling systems. Agric. Water Manag., 148, 258-268. https://doi.org/10.1016/j.agwat.2014.10.015

Topp, G. C., Davis, J. L., \& Annan, A. P. (1980). Electromagnetic determination of soil water content: Measurements in coaxial transmission lines. Water Resour. Res., 16(3), 574-582. https://doi.org/10.1029/WR016i003p00574

Vaz, C. M., Jones, S., Meding, M., \& Tuller, M. (2013). Evaluation of standard calibration functions for eight electromagnetic soil moisture sensors. Vadose Zone J., 12(2). https://doi.org/10.2136/vzj2012.0160 
Visconti, F., de Paz, J. M., Martinez, D., \& Molina, J. M. (2014). Laboratory and field assessment of the capacitance sensors Decagon 10HS and 5TE for estimating the water content of irrigated soils. Agric. Water Manag., 132, 111-119. https://doi.org/10.1016/j.agwat.2013.10.005

Western, A. W., \& Seyfried, M. S. (2005). A calibration and temperature correction procedure for the water-content reflectometer. Hydrol. Process., 19(18), 3785-3793.

https://doi.org/10.1002/hyp.6069
White, I., Knight, J. H., Zegelin, S. J., \& Topp, G. C. (1994). Comments on - Considerations on the use of time-domain reflectometry (TDR) for measuring soil water content by WR Whalley. European J. Soil Sci., 45(4), 503-508. https://doi.org/10.1111/j.1365-2389.1994.tb00536.x

Wraith, J. M., \& Or, D. (1999). Temperature effects on soil bulk dielectric permittivity measured by time domain reflectometry: Experimental evidence and hypothesis development. Water Resour. Res., 35(2), 361-369.

https://doi.org/10.1029/1998WR900006 